Supporting Information for

\title{
Cations Block Hydrogen-Bonding-Driven Ethanol Permeation through Disordered Drop- Cast Graphene Oxide Membranes
}

Richard B. Church, ${ }^{1}$ Kaiwen Hu, ${ }^{1}$ Giuliana Magnacca,${ }^{2}$ Marta Cerruti ${ }^{1, *}$

${ }^{1}$ Department of Mining and Materials Engineering, McGill University, Montreal, Quebec, Canada H3A 0E8

${ }^{2}$ Department of Chemistry and NIS Interdepartmental Center, University of Turin, Turin, Italy 10125

This document contains supporting information on:

1) Experimental Methods:

Section 1: GO Membrane Fabrication

Section 2: In situ FTIR Spectroscopy Assembly

2) Results and Discussion:

Section 3: GO Characterization

Section 4: Structural Analysis for Ion Modified GO Membranes

Section 5: Compositional Analysis for Ion Modified GO Membranes

Section 6: Ion Modified GO Permeation Tests

Section 7: FTIR Spectra for GO and Ion Modified GO Membranes Prior to Probe Molecule Delivery

Section 8: Probe Molecule Deliveries to GO and Ion Modified GO Membranes

Section 9: Characterization for NaCl-GO Membranes with Varying Ion Concentrations

Section 10: Acid-Base Titrations 
Add ion solution for desired final ion concentration (0.001-0.1 M)

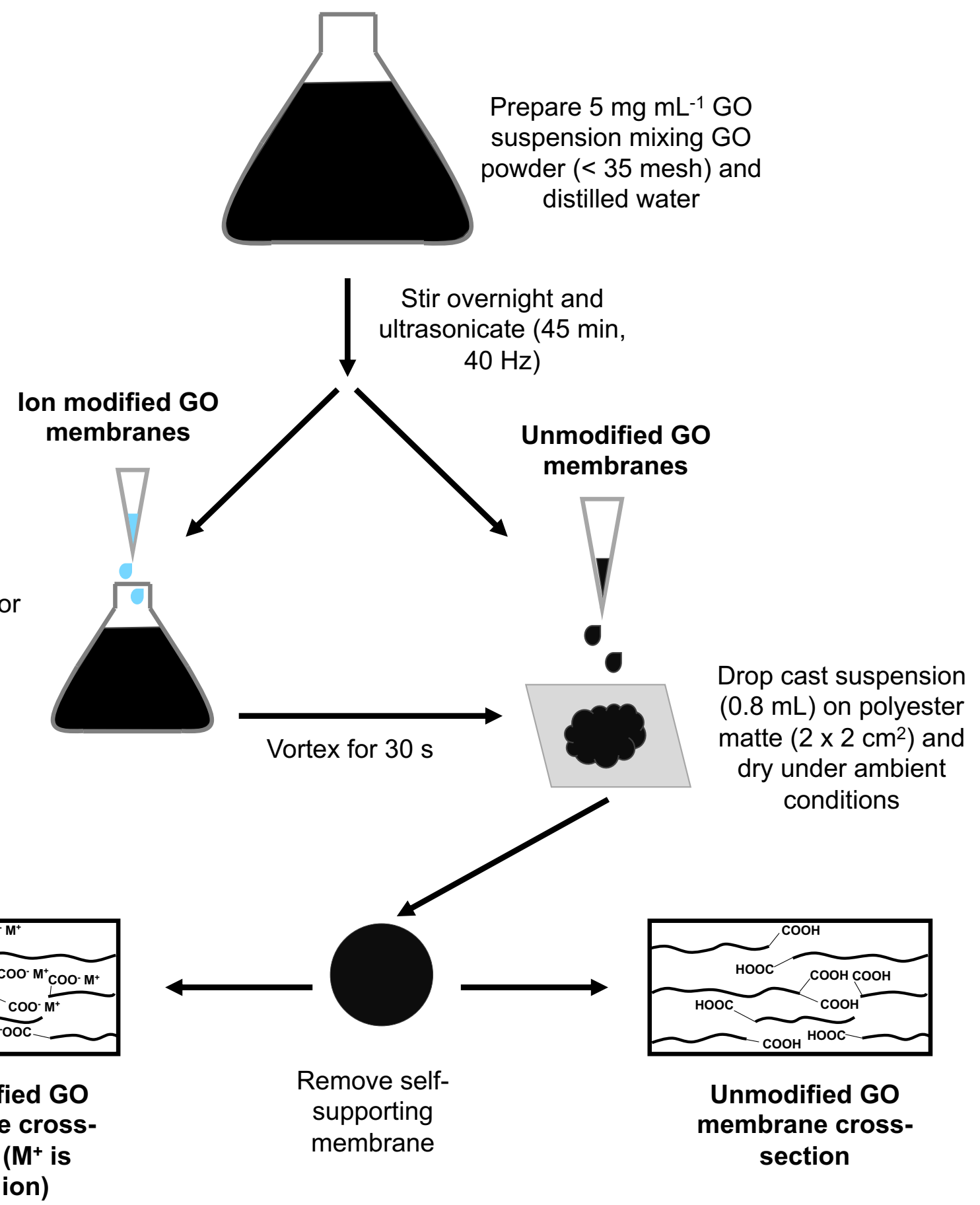

Figure S1: Procedure for fabricating drop cast $\mathrm{GO}$ and $\mathrm{NaCl}-\mathrm{GO}$ membranes 


\section{A}

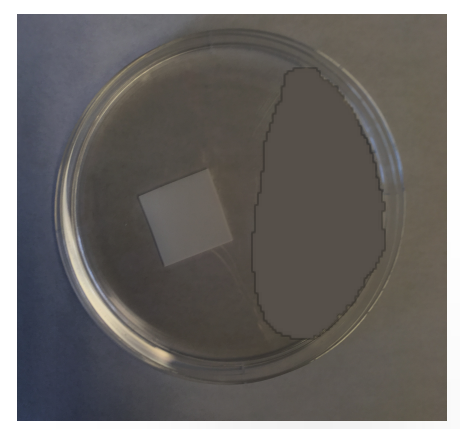

C

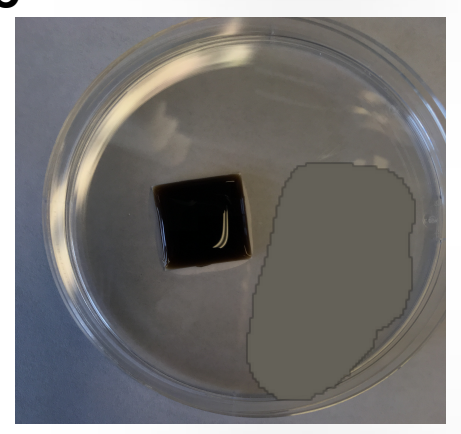

B

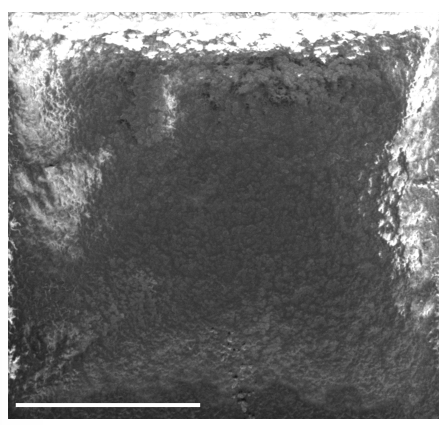

D

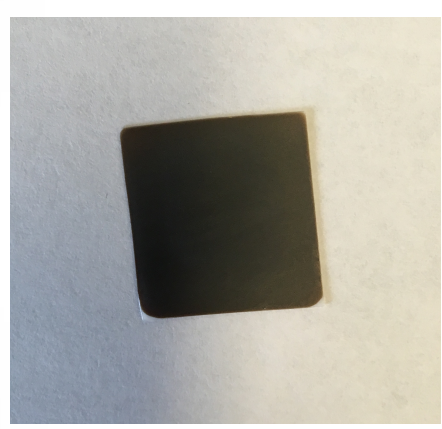

Figure S2: Drop cast GO membrane fabrication. (A) $4 \mathrm{~cm}^{2}$ Dura-Lar polyester matte, (B) SEM image for Dura-Lar polyester matte showing its non-porous nature, (C) $0.8 \mathrm{~mL}$ of GO suspension deposited on Dura-Lar polyester matte and (D) GO membrane on Dura-Lar polyester matte dried under ambient conditions. Scale bar at $400 \mu \mathrm{m}$. 
Section 2: In situ FTIR Spectroscopy Assembly

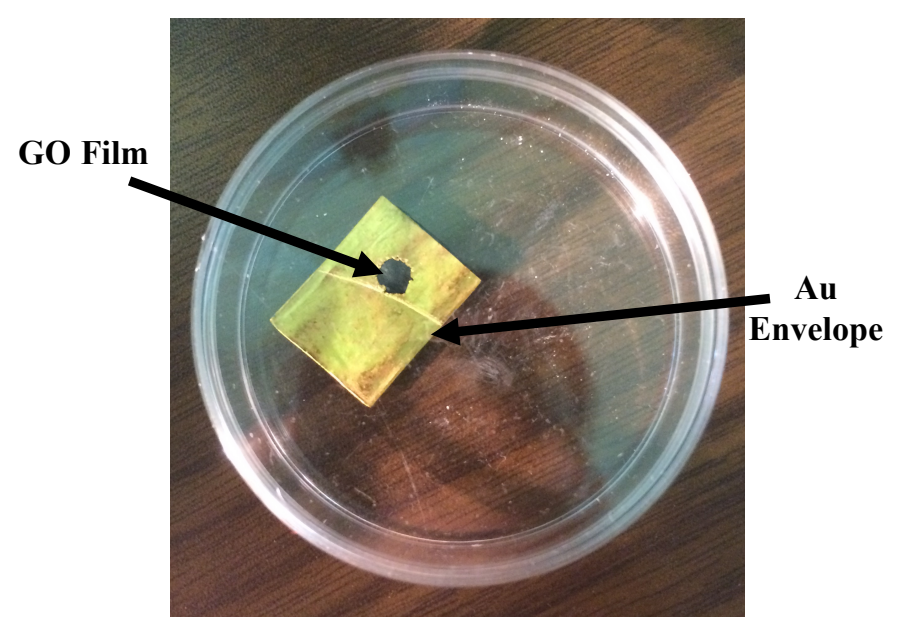

Figure S3: GO film in Au envelope.

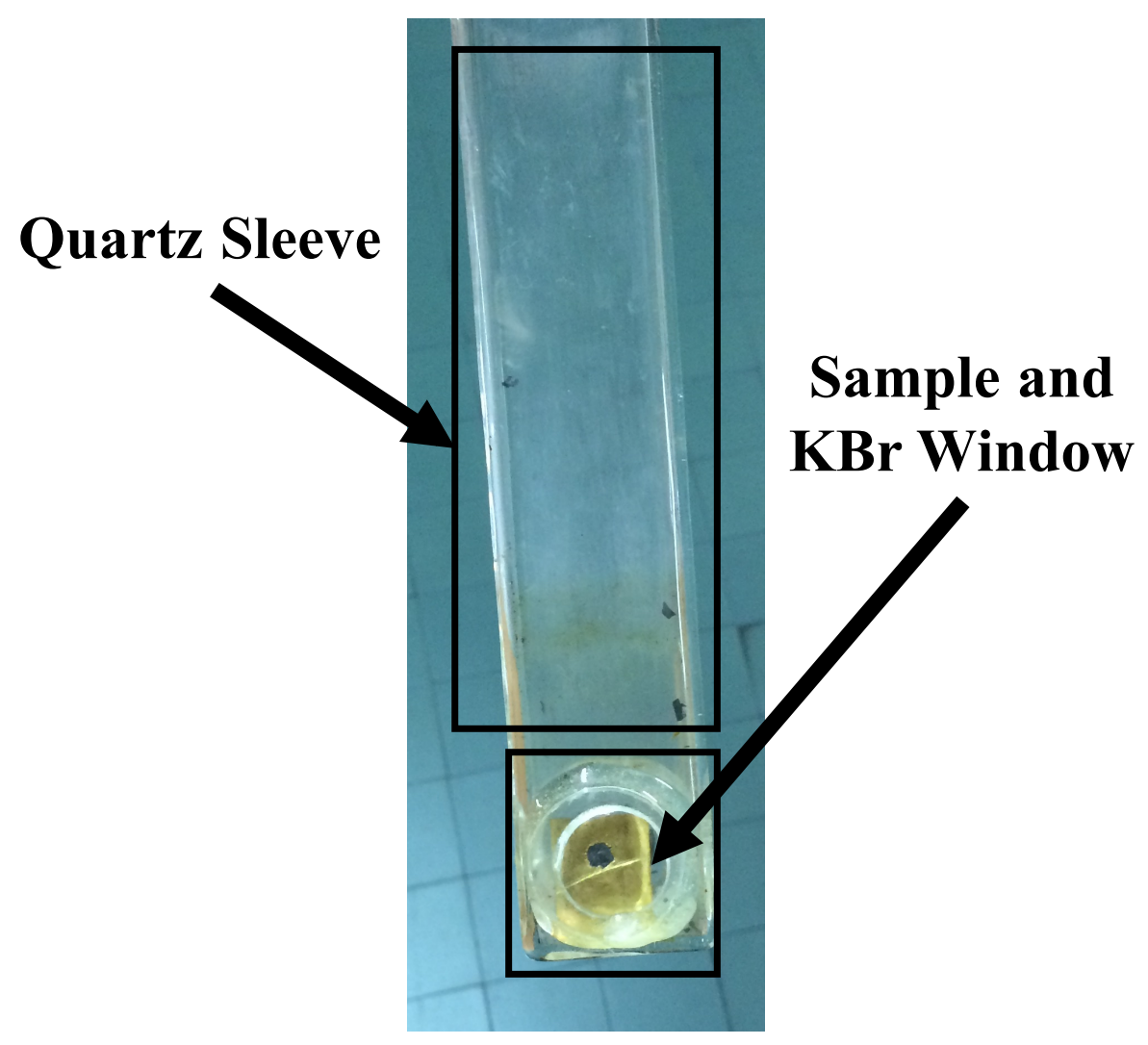

Figure S4: Sample inside homemade quartz cell. 


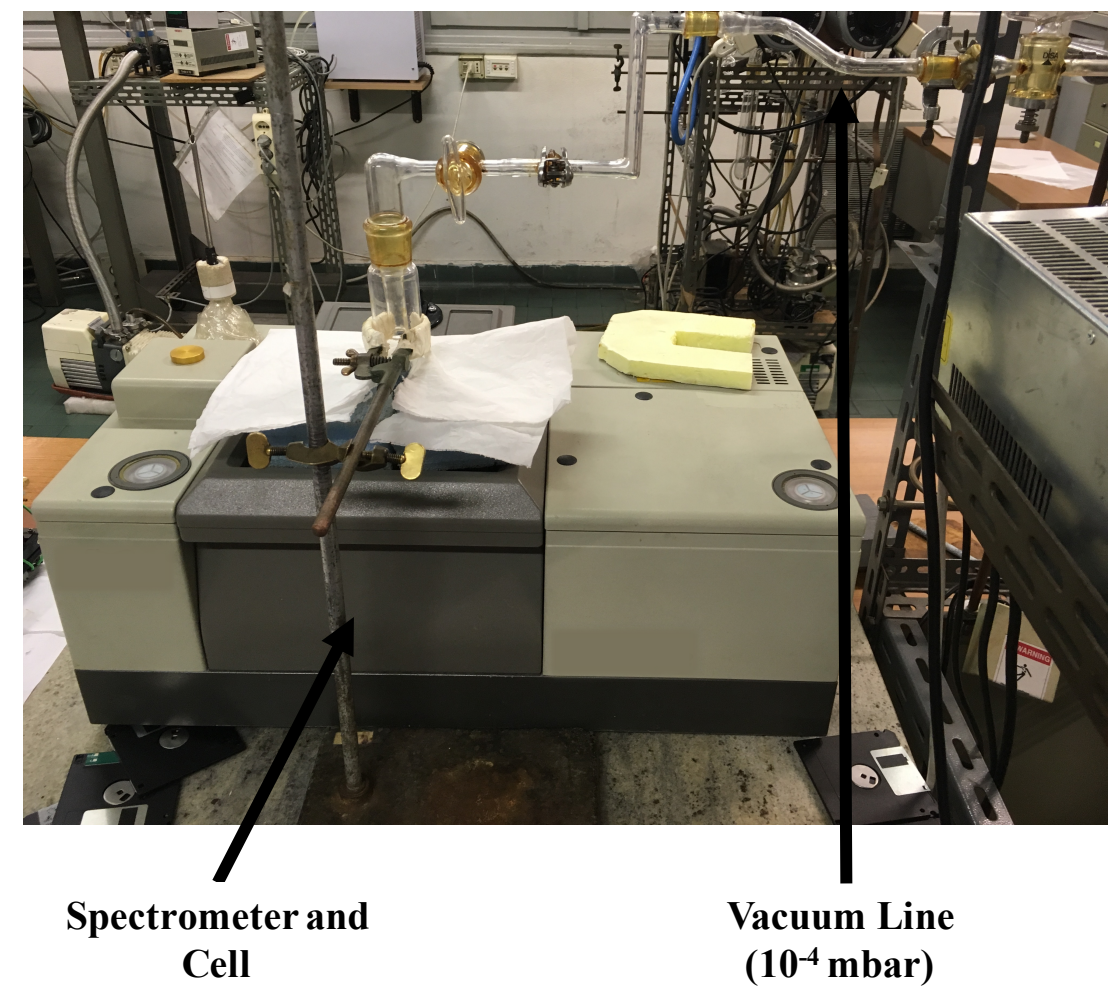

Figure S5: Spectrometer and cell connected to vacuum line.

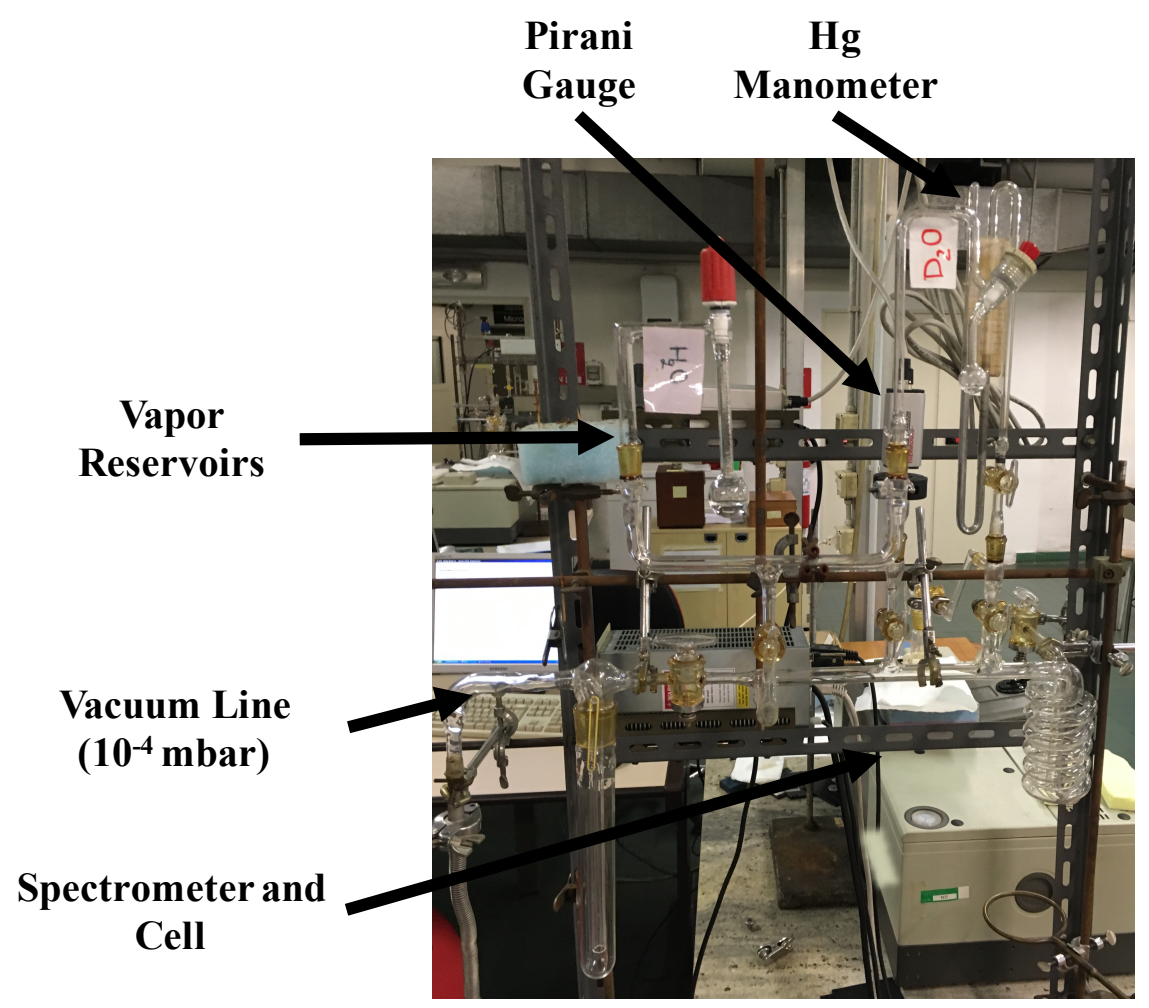

Figure S6: Vacuum line assembly. 


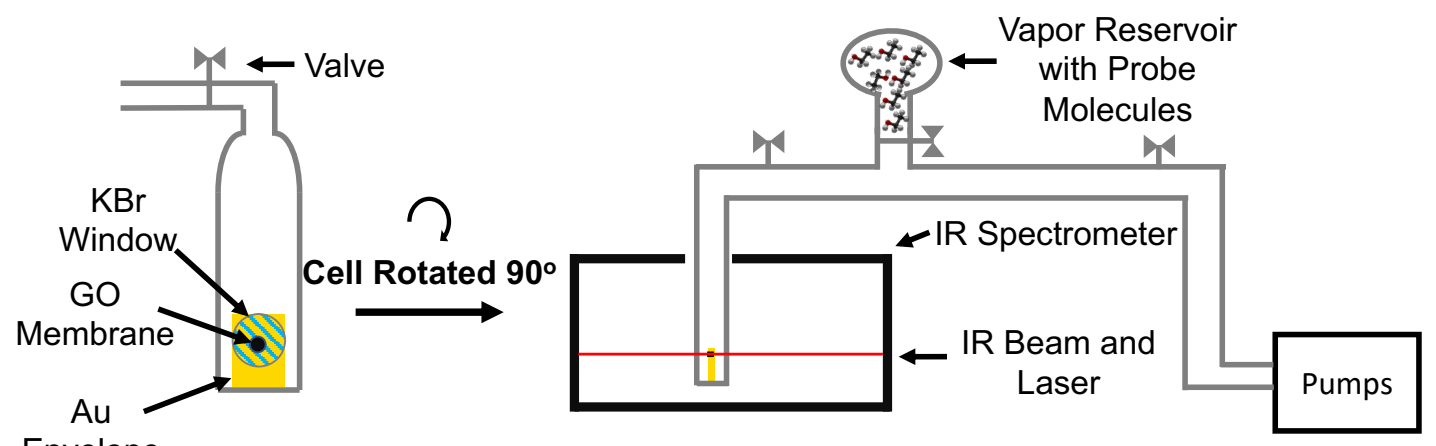

Envelope

Step 1: GO film

in Au envelope is inserted into homemade cell. The GO film is aligned inside the $\mathrm{KBr}$ window.
Step 2: The cell is inserted into the IR spectrometer and aligned so the beam can pass through the sample via the hole in the Au envelope. Once the sample is aligned a reference spectrum is collected under air. Then the valve to the pumps is opened to evacuate the line.

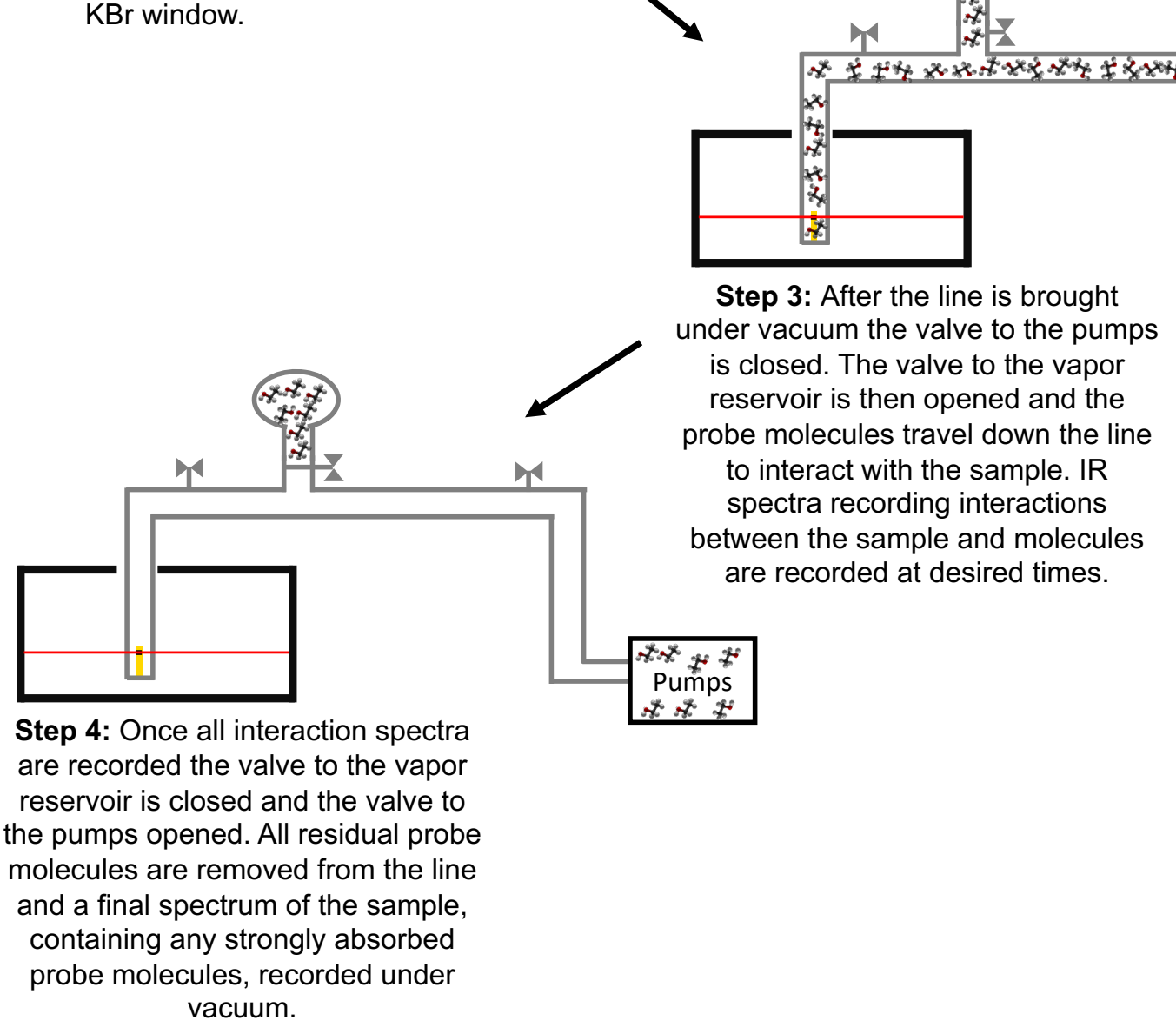

Figure S7: Procedure for performing and analyzing a probe molecule delivery with in situ FTIR spectroscopy. 


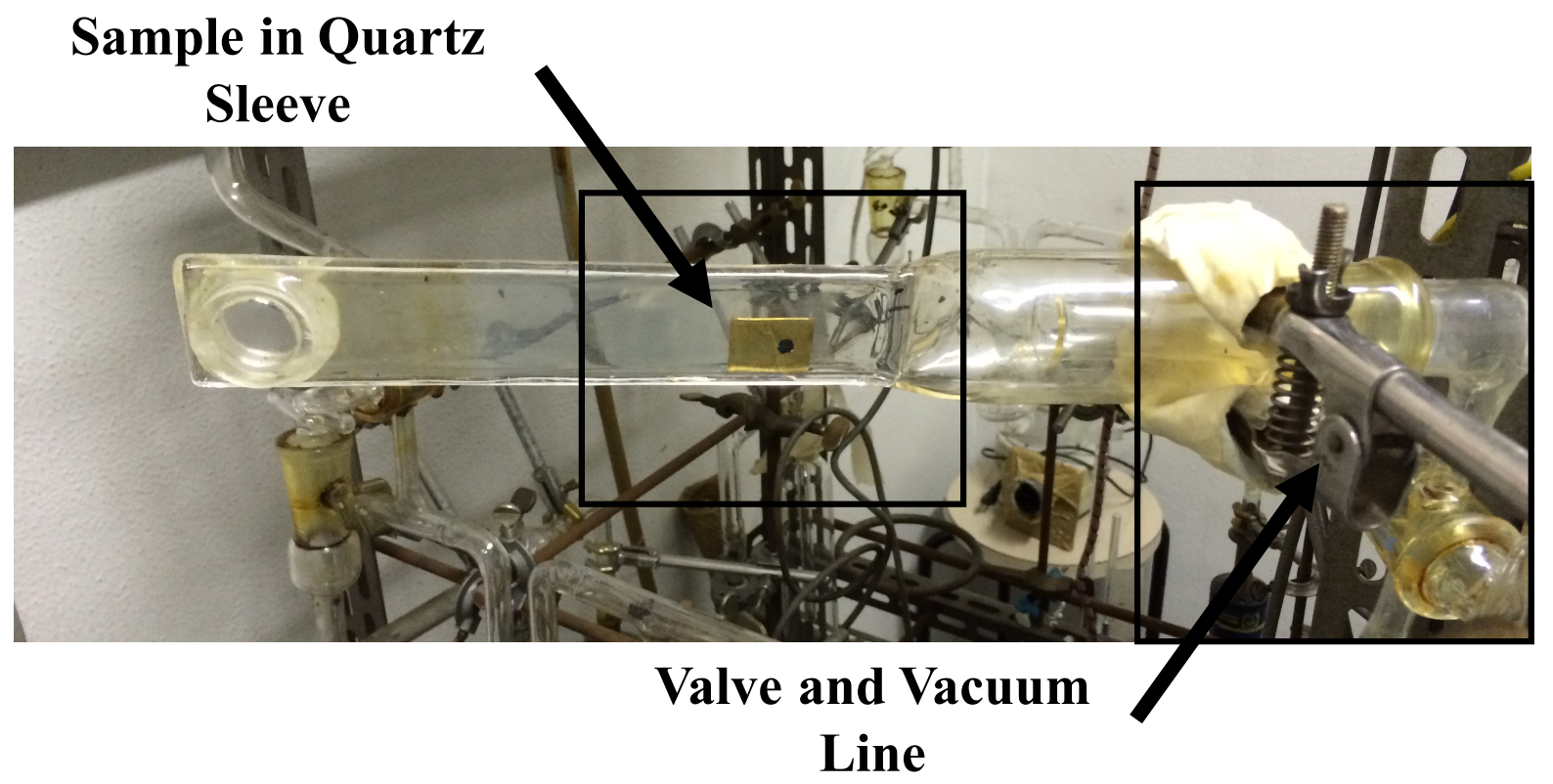

Figure S8: Experimental setup for thermal treatment.

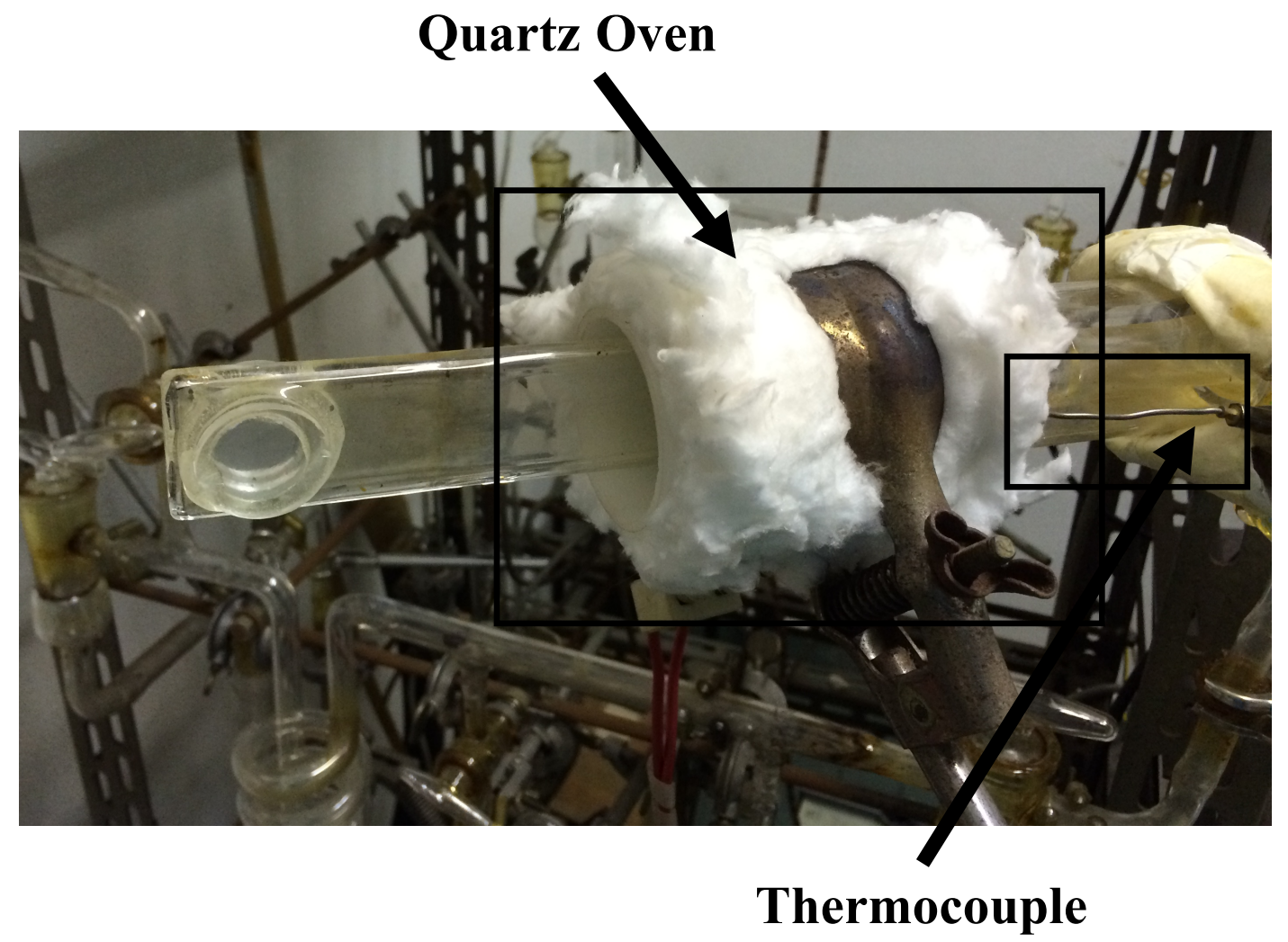

Figure S9: Cell with oven for thermal treatment. 
Section 3: GO Characterization

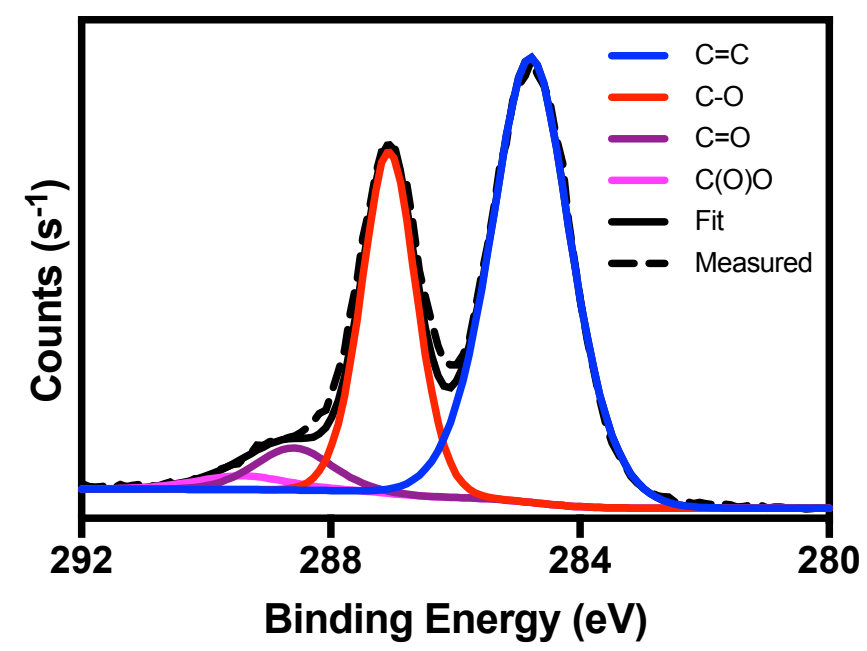

Figure S10: XPS C1s spectra for GO purchased from Abalonyx.

Table S1: C1s peak fitting for GO purchased from Abalonyx.

\begin{tabular}{|c|c|c|c|}
\hline Peak & Peak Location (eV) & Average At. \% & STD \\
\hline C=C & 284.8 & 62 & 3 \\
\hline C-0 & 287.1 & 30 & 5 \\
\hline C=0 & 288.45 & 6 & 1 \\
\hline C(O)O & 289.4 & 1.6 & 0.6 \\
\hline
\end{tabular}




\section{Section 4: Structural Analysis for Ion Modified GO Membranes}

A

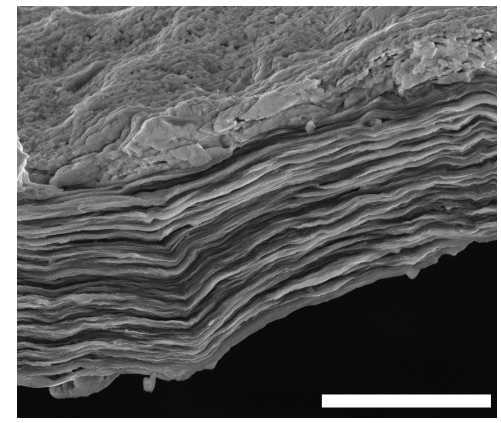

C

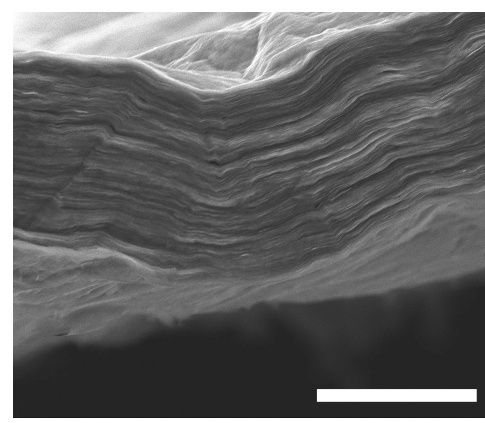

B

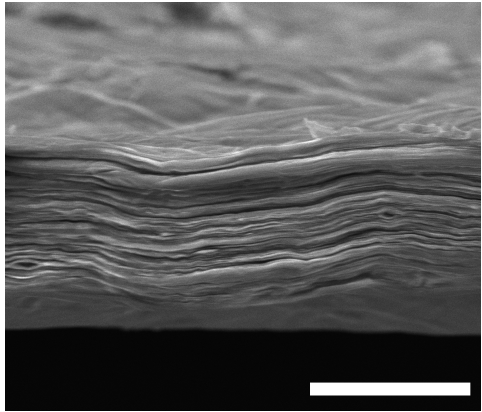

D

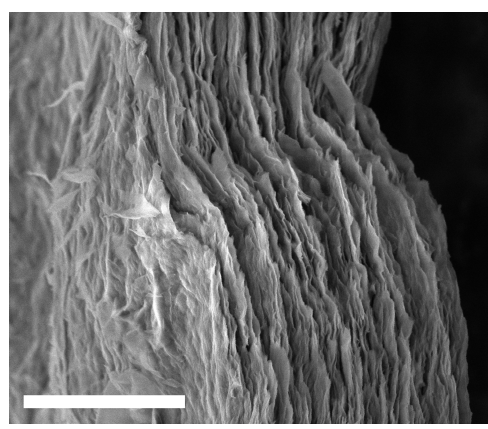

Figure S11: SEM images for ion modified GO cross-sections. (A) NaOH-GO, (B) $\mathrm{NH}_{4} \mathrm{OH}-\mathrm{GO}$, (C) $\mathrm{NH}_{4} \mathrm{Cl}-\mathrm{GO}$ and (D) $\mathrm{CaCl}_{2}-\mathrm{GO}$ membranes. Scale bars at $5 \mu \mathrm{m}$.

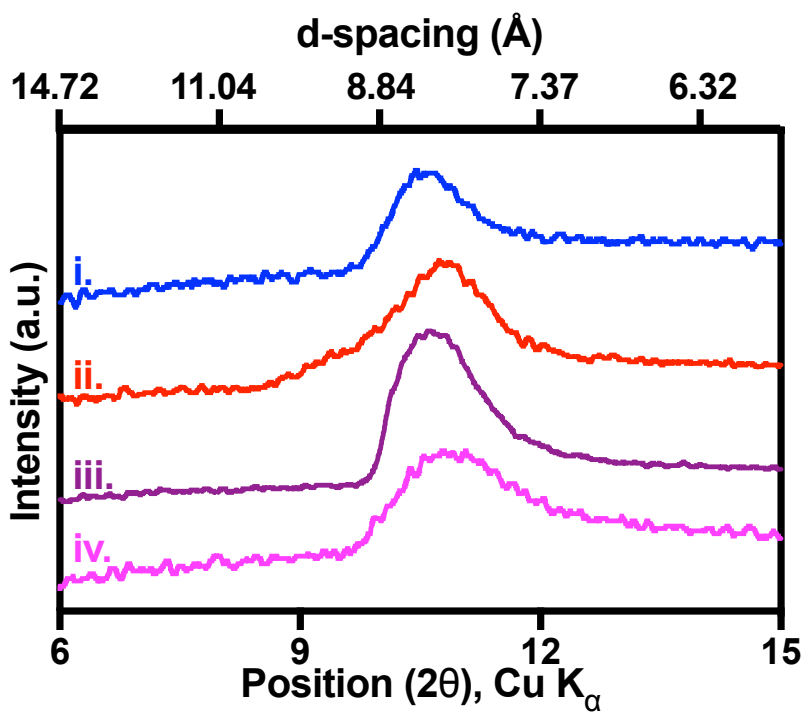

Figure S12: XRD patterns for ion modified GO membranes. (i) $\mathrm{NaOH}-\mathrm{GO}$ (ii) $\mathrm{NH}_{4} \mathrm{OH}-\mathrm{GO}$, (iii) $\mathrm{NH}_{4} \mathrm{Cl}-\mathrm{GO}$ and (iv) $\mathrm{CaCl}_{2}-\mathrm{GO}$ membranes. 
Like NaCl-GO, all ion modified GO membranes (Figure S11) show increased interlayer aggregation compared to GO membranes (Figure 1B) due to electrostatic screening, wrinkling and cross-linking. ${ }^{1-3}$ Previous works show GO suspensions are more stable in basic suspension due to increased negative charge on the GO sheets. ${ }^{4-5}$ For aggregation to occur under basic conditions, the $\mathrm{NaOH}$ concentration needs to exceed a value double $(0.044 \mathrm{M})$ the one used in this work. We would expect this value to be even higher for $\mathrm{NH}_{4} \mathrm{OH}$, due to the bigger cation size and lower degree of dissociation. The aggregation in the hydroxide membranes likely occurs during the drying process, when the ion concentration becomes high. $\mathrm{NaOH}-\mathrm{GO}, \mathrm{NH}_{4} \mathrm{OH}-\mathrm{GO}, \mathrm{NH}_{4} \mathrm{Cl}-\mathrm{GO}$ and $\mathrm{CaCl}_{2}-\mathrm{GO}$ membranes exhibit a small increase in spacing compared to $\mathrm{GO}$ membranes (Figure S12), in agreement with previous works. ${ }^{2,6}$ 
Section 5: Compositional Analysis for Ion Modified GO Membranes

Table S2: Average atomic composition from XPS survey scans.

\begin{tabular}{|c|c|c|c|c|c|c|}
\hline Sample & \multicolumn{2}{|c|}{ GO } & \multicolumn{2}{|c|}{$\mathrm{NaCl}-\mathrm{GO}$} & \multicolumn{2}{|c|}{$\mathrm{NaOH}-\mathrm{GO}$} \\
\hline Element & Average At. \% & STD & Average At. \% & STD & Average At. \% & STD \\
\hline C & 73.6 & 0.3 & 65 & 2 & 66 & 2 \\
\hline 0 & 25.6 & 0.2 & 31 & 2 & 31 & 2 \\
\hline $\mathbf{S}$ & 0.84 & 0.05 & 0.7 & 0.1 & 0.2 & 0.2 \\
\hline $\mathrm{Na}$ & - & - & 2.1 & 0.2 & 3.0 & 0.5 \\
\hline $\mathrm{Cl}$ & - & - & 1.28 & 0.09 & - & - \\
\hline Sample & \multicolumn{2}{|c|}{$\mathrm{NH}_{4} \mathrm{OH}-\mathrm{GO}$} & \multicolumn{2}{|c|}{$\mathrm{NH}_{4} \mathrm{Cl}-\mathrm{GO}$} & \multicolumn{2}{|c|}{$\mathrm{CaCl}_{2}-\mathrm{GO}$} \\
\hline Element & Average At. \% & STD & Average At. \% & STD & Average At. \% & STD \\
\hline C & 68.7 & 0.3 & 63 & 3 & 61 & 2 \\
\hline 0 & 30 & 0.4 & 30 & 3 & 31 & 3 \\
\hline$S$ & 0.35 & 0.04 & 0.6 & 0.5 & 0.3 & 0.5 \\
\hline $\mathbf{N}$ & 1.0 & 0.2 & 3.6 & 0.1 & - & - \\
\hline $\mathrm{Ca}$ & - & - & - & - & 3.6 & 0.9 \\
\hline $\mathrm{Cl}$ & - & - & 2.29 & 0.09 & 3.9 & 0.5 \\
\hline
\end{tabular}

The smaller $\mathrm{N}$ content in the $\mathrm{NH}_{4} \mathrm{OH}-\mathrm{GO}$ membrane (Table $\mathrm{S} 2$ ) compared to the $\mathrm{NH}_{4} \mathrm{Cl}$ GO membrane could result from ammonia evaporation during drying. The $\mathrm{S}$ content in the initial GO product is $<1$ At. \%, in agreement with the specifications provided by the suppliers, indicating a pure starting product, and the GO membranes are free from any ion contamination. The GO membranes have a $\mathrm{C} / \mathrm{O}$ ratio of $2.86 \pm 0.02$. 

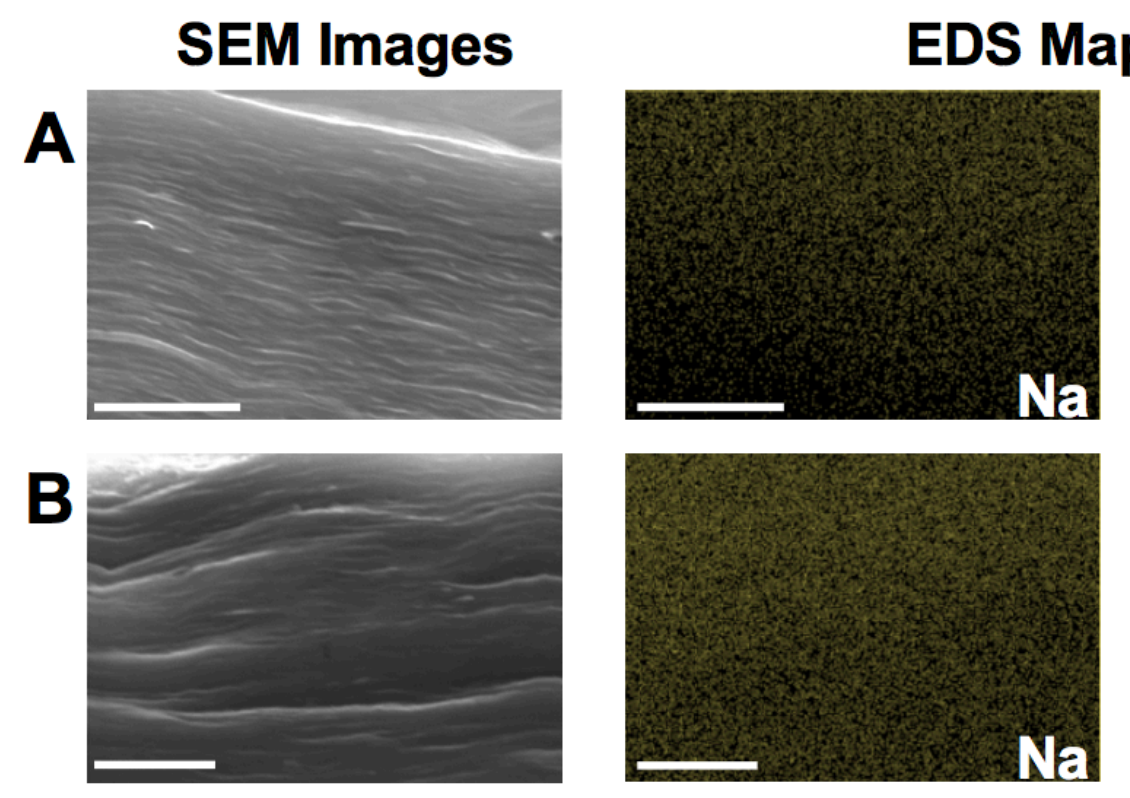

EDS Mapping
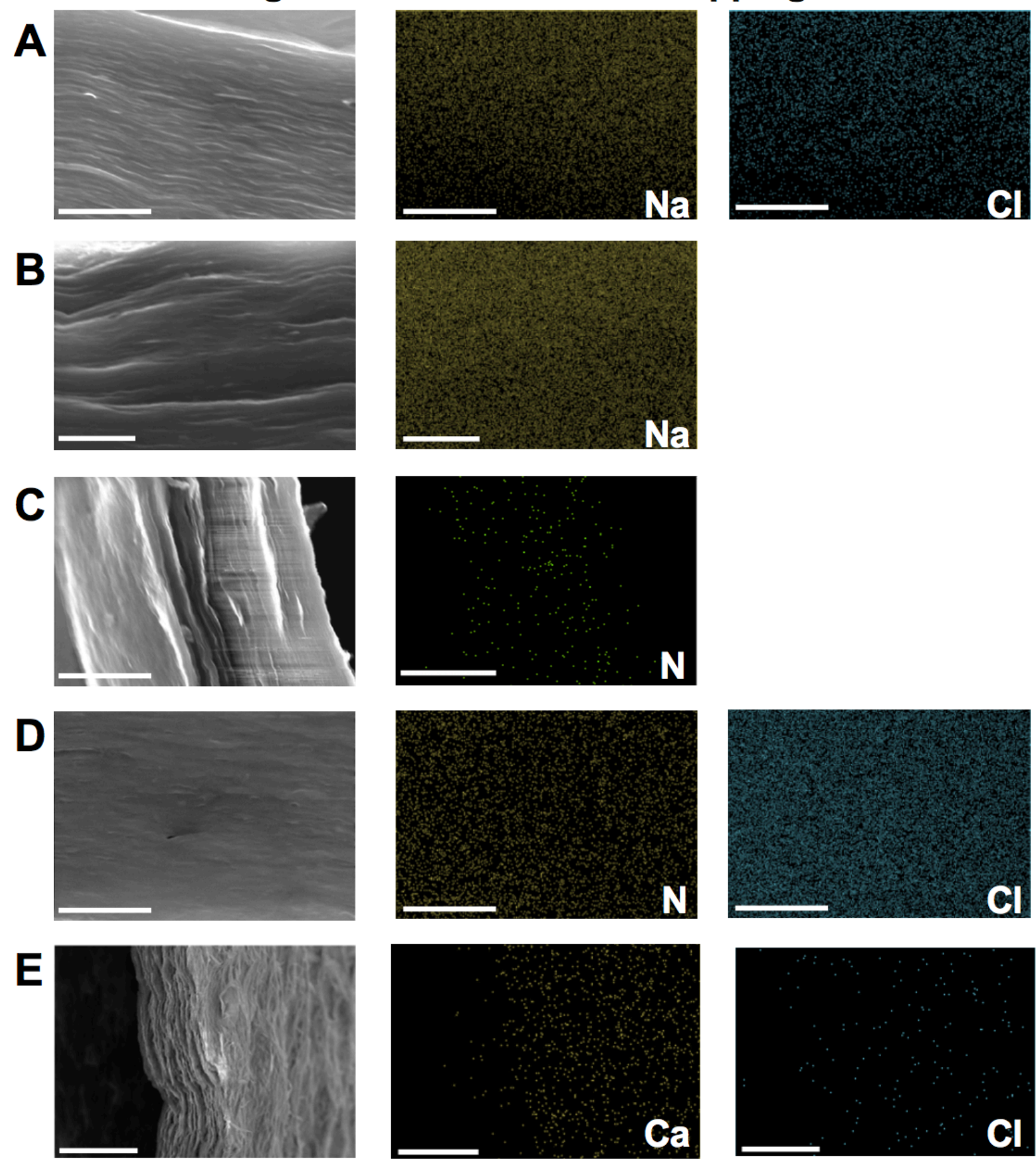

Figure S13: EDS analysis for ion modified GO membranes. (A) NaCl-GO, (B) NaOH-GO, (C) $\mathrm{NH}_{4} \mathrm{OH}-\mathrm{GO}$, (D) $\mathrm{NH}_{4} \mathrm{Cl}-\mathrm{GO}$ and (E) $\mathrm{CaCl}_{2}-\mathrm{GO}$. All scale bars are set at $10 \mu \mathrm{m}$, except for (E) which is at $5 \mu \mathrm{m}$. 
Ion species are detectable in all ion modified membranes following drying and are distributed throughout the membrane cross-section (Figure S13). The detectable N content in the $\mathrm{NH}_{4} \mathrm{OH}-\mathrm{GO}$ membrane cross-section is lower than $\mathrm{NH}_{4} \mathrm{Cl}-\mathrm{GO}$, agreeing with the At. \% from the XPS survey spectra (Table S2).

A

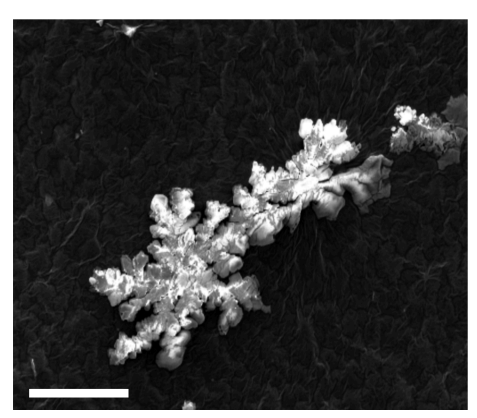

B

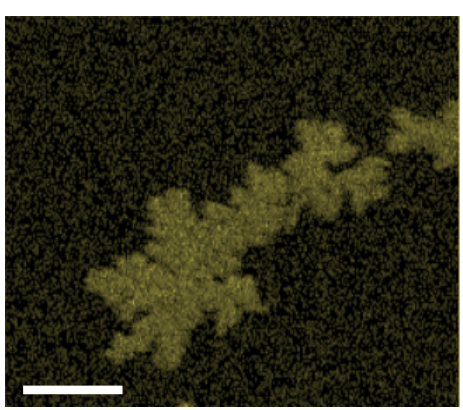

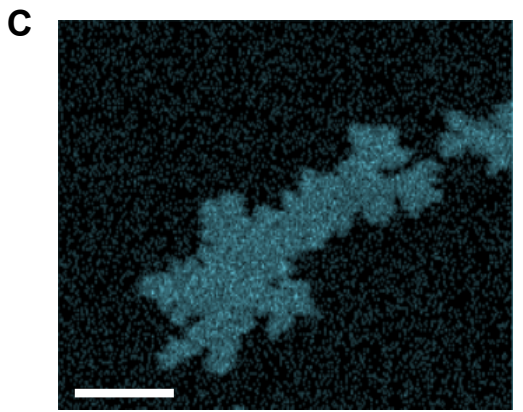

Figure S14: NaCl-GO membrane surface. (A) SE of membrane surface showing a salt crystal, (B) $\mathrm{Na} \mathrm{X}$-ray mapping, (C) $\mathrm{Cl} \mathrm{X}$-ray mapping. All scale bars are set at $100 \mu \mathrm{m}$.

Salt crystals (Figure S14) were distributed across the $\mathrm{NaCl}-\mathrm{GO}$ and $\mathrm{NH}_{4} \mathrm{Cl}-\mathrm{GO}$ membrane surfaces, but concentrated near the membrane center. The drop cast membranes dry from the edges inward, and this likely creates a high ion concentration in the membranes center thus resulting in salt formation. 


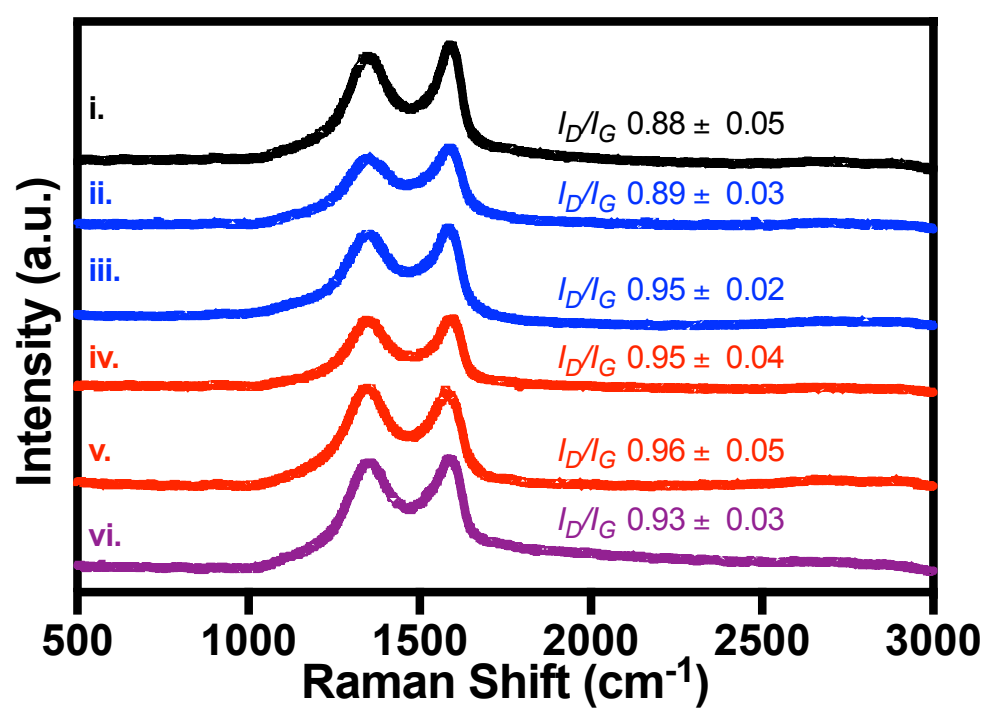

Figure S15: Raman spectra with $\mathrm{D} / \mathrm{G}$ ratio for $\mathrm{GO}$ and ion modified $\mathrm{GO}$ membranes. (i) GO, (ii) $\mathrm{NaCl}-\mathrm{GO}$, (iii) $\mathrm{NaOH}-\mathrm{GO}$, (iv) $\mathrm{NH}_{4} \mathrm{OH}-\mathrm{GO}$, (v) $\mathrm{NH}_{4} \mathrm{Cl}-\mathrm{GO}$ and (vi) $\mathrm{CaCl}_{2}-\mathrm{GO}$.

All membranes show the characteristic G-band at $1595 \mathrm{~cm}^{-1}$ and D-band at $\sim 1330 \mathrm{~cm}^{-1}$, corresponding to the vibrations in the $s p^{2}$ lattice and defect induced vibration in $s p^{2}$ lattice respectfully, and ion addition has no major impact on the D/G ratio (Figure $\mathrm{S} 15)^{7}$ 
Section 6: Ion Modified GO Permeation Tests
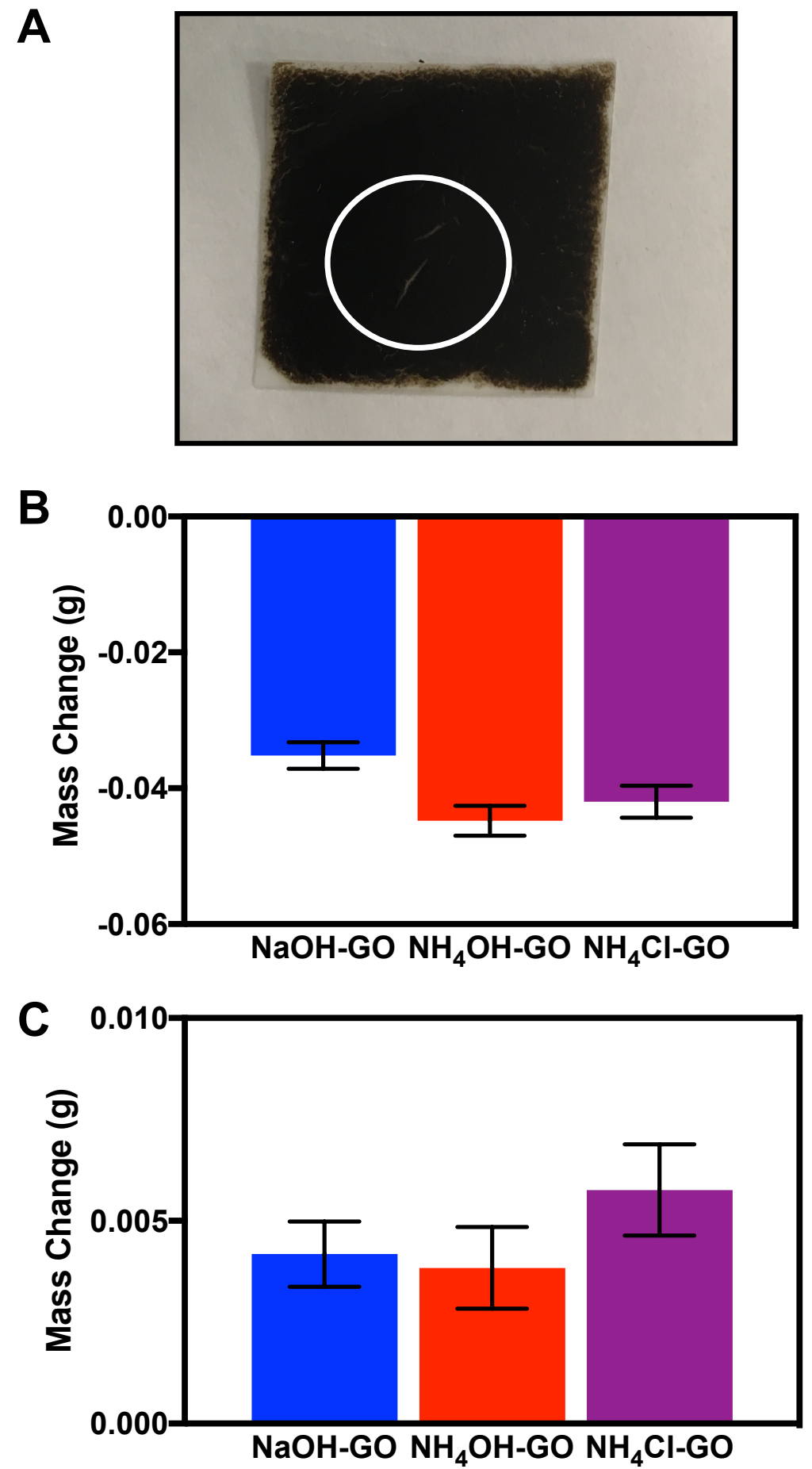

Figure S16: Additional permeation test data for ion modified GO membranes. (A) Macroscopic defects in a dried $\mathrm{CaCl}_{2}-\mathrm{GO}$ membrane, (B) Mass changes for water containing vials and (C) Mass changes for EtOH containing vials. Error bars correspond to plus or minus one standard deviation. All measurements are significantly different from zero at $95 \%$ confidence. 
Macroscopic defects (Figure S16A) made it impossible to perform separation tests with $\mathrm{CaCl}_{2}$-GO membranes. We attribute this behavior to increased $\mathrm{GO}$ flake aggregation in suspension caused by $\mathrm{Ca}^{2+}$ s larger screening effect and ability to cross link GO sheets. ${ }^{1-2,8-9}$ In fact the GO suspension visibly aggregates when the $\mathrm{CaCl}_{2}$ solution is added. $\mathrm{NaOH}-\mathrm{GO}, \mathrm{NH}_{4} \mathrm{OH}-\mathrm{GO}$ and $\mathrm{NH}_{4} \mathrm{Cl}-\mathrm{GO}$ membranes allow water permeation (Figure S16B) but are impermeable to EtOH vapor (Figure S16C), in line with the NaCl-GO results. 
Section 7: FTIR Spectra for GO and Ion Modified GO Membranes Prior to Probe Molecule Delivery
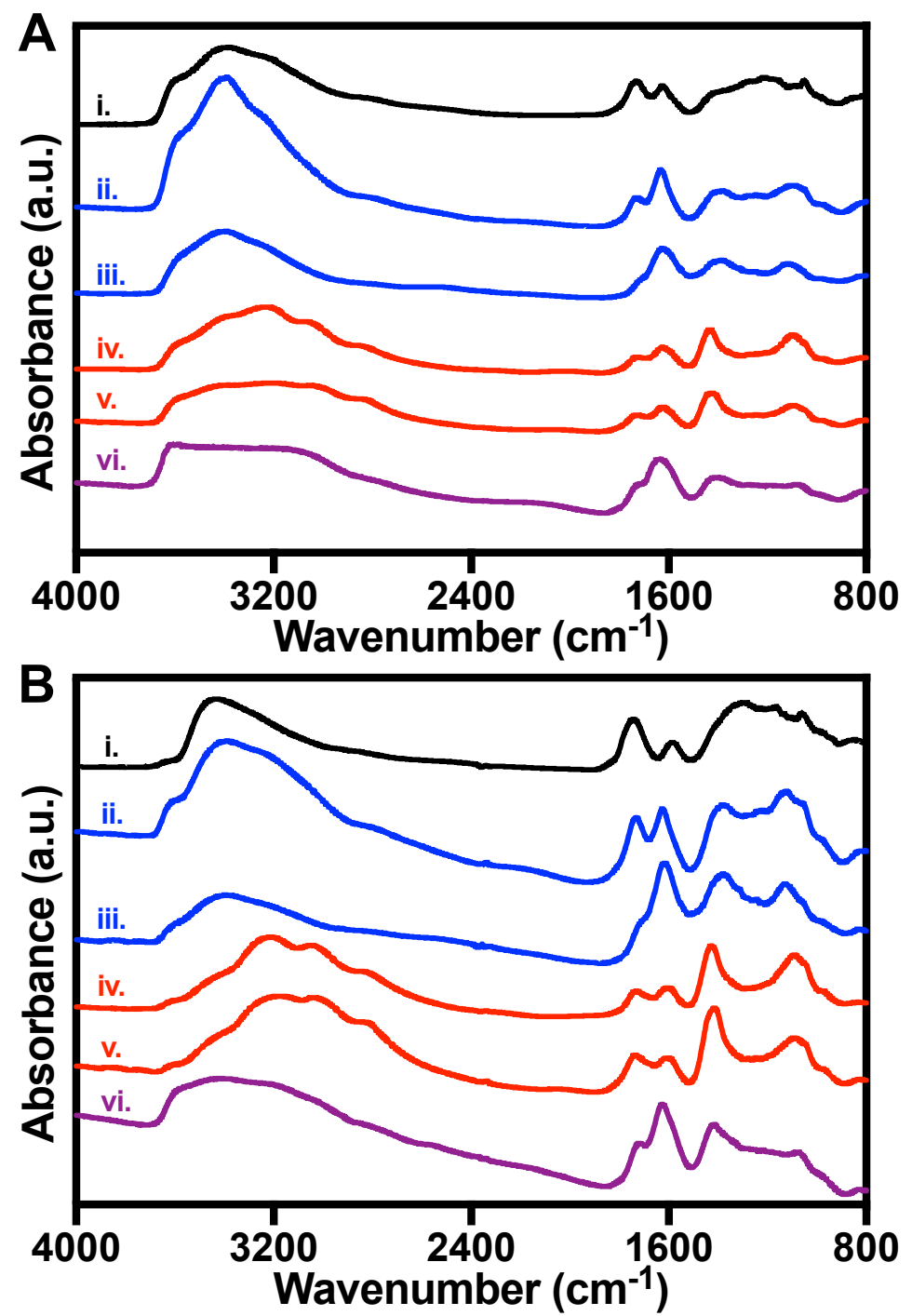

Figure S17: IR spectra for GO membranes prior to probe molecule delivery (A) under air and (B) under vacuum ( $10^{-4}$ mbar). (i) $\mathrm{GO}$, (ii) $\mathrm{NaCl}-\mathrm{GO}$, (iii) $\mathrm{NaOH}-\mathrm{GO}$, (iv) $\mathrm{NH}_{4} \mathrm{OH}-\mathrm{GO}$, (v) $\mathrm{NH}_{4} \mathrm{Cl}-$ $\mathrm{GO}$ and (vi) $\mathrm{CaCl}_{2}-\mathrm{GO}$.

Both GO and ion modified GO membrane spectra (Figure S17A) show a large band from $\sim 3000-3700 \mathrm{~cm}^{-1}$, corresponding to hydroxyl and carboxyl groups along with intercalated water molecules $\left(v_{\mathrm{O}}-\mathrm{H}\right)$, a distinct carbonyl signal $\left(v_{\mathrm{C}=\mathrm{O}}\right)$ at $\sim 1730 \mathrm{~cm}^{-1}$, and a peak at $\sim 1550 \mathrm{~cm}^{-1}$ that is due to both in plane stretching of $s p^{2}$ carbons $\left(v_{\mathrm{C}=\mathrm{C}}\right)$ and bending of intercalated water molecules 
$\left(\delta_{\mathrm{H} 20}\right) \cdot{ }^{10-11}$ Despite these similarities there are several differing peaks in the finger print region between $800-1500 \mathrm{~cm}^{-1}$ for GO (i) and ion modified GO (ii-vi) membranes. Due to the overlapping of numerous signals and varying relative intensities, the bands in this region are difficult to identify. ${ }^{2,10-12}$ The spectra for $\mathrm{NH}_{4} \mathrm{OH}-\mathrm{GO}$ (iv) and $\mathrm{NH}_{4} \mathrm{Cl}-\mathrm{GO}$ (v) show a peak at $\sim 1440 \mathrm{~cm}^{-1}$, corresponding to $\mathrm{N}-\mathrm{H}$ stretching $\left(v_{\mathrm{N}-\mathrm{H}}\right)$ in the $\mathrm{NH}_{4}{ }^{+}$ion, while the three distinct peaks in the band between $2700-3400 \mathrm{~cm}^{-1}$ are attributed to an overlap of $v_{\mathrm{N}-\mathrm{H}}$ and $v_{\mathrm{O}-\mathrm{H}}$ of water molecules coordinated to the $\mathrm{NH}_{4}{ }^{+}$ions. ${ }^{13}$

The $v_{\mathrm{O}-\mathrm{H}}$ and $\delta_{\mathrm{H} 2 \mathrm{O}}$ bands decrease when the sample is brought under vacuum, indicating physisorbed water removal (Figure S17B). ${ }^{14-15}$ Following outgassing the NaCl-GO, NaOH-GO and $\mathrm{CaCl}_{2}-\mathrm{GO}$ exhibit a stronger $v_{\mathrm{O}}-\mathrm{H}$ at $\sim 3600 \mathrm{~cm}^{-1}$ than the other membranes. This indicates the sodium or calcium modified membranes hold more intercalated water under vacuum due to strong coordination between the $\mathrm{Na}^{+}$or $\mathrm{Ca}^{2+}$ ions and the water molecules in the GO. ${ }^{16}$

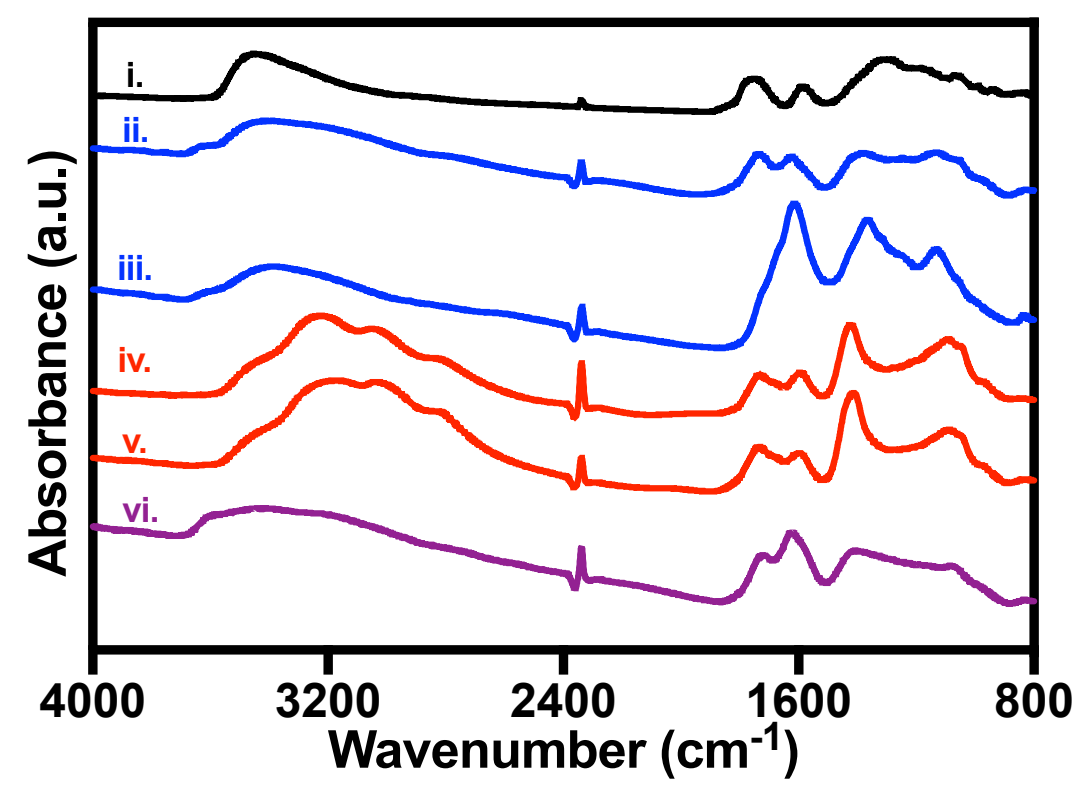

Figure S18: IR spectra for GO membranes prior to probe molecule delivery and following thermal treatment at $125^{\circ} \mathrm{C}$ for 10 min. (i) GO, (ii) $\mathrm{NaCl}-\mathrm{GO}$, (iii) $\mathrm{NaOH}-\mathrm{GO}$, (iv) $\mathrm{NH}_{4} \mathrm{OH}-\mathrm{GO}$, (v) $\mathrm{NH}_{4} \mathrm{Cl}-\mathrm{GO}$ and (vi) $\mathrm{CaCl}_{2}-\mathrm{GO}$. 
Following thermal treatment, all membranes retain intercalated $\mathrm{CO}_{2}$, as evident by the formation of a peak at $\sim 2337 \mathrm{~cm}^{-1}$ that corresponds to the $v_{\mathrm{C}=\mathrm{O}}$ stretching mode of intercalated $\mathrm{CO}_{2}$ (symmetry species $\Sigma_{\mathrm{u}}{ }^{+}$) (Figure $\left.\mathrm{S} 18\right) \cdot{ }^{14,17}$ The intercalated $\mathrm{CO}_{2}$ signal's relative intensity is much lower in the spectra for unmodified GO (i) than for the ion modified films (ii-vi). The increased $\mathrm{CO}_{2}$ production in the $\mathrm{NaOH}-\mathrm{GO}, \mathrm{NaCl}-\mathrm{GO}$ and $\mathrm{CaCl}_{2}-\mathrm{GO}$ membranes can be explained by the increased intercalated water content under vacuum, as intercalated $\mathrm{CO}_{2}$ production is linked to the

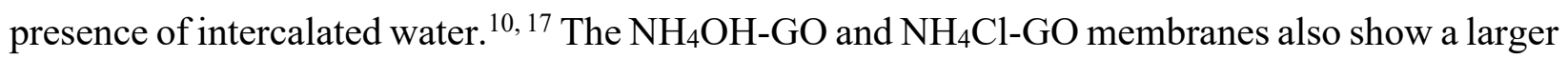
intercalated $\mathrm{CO}_{2}$ signal despite having a water retention like unmodified GO. Liquid ammonium has gathered interest for $\mathrm{CO}_{2}$ capture due to its strong interactions with $\mathrm{CO}_{2} \cdot{ }^{18}$ The $\mathrm{NH}_{4}{ }^{+}$ions in the $\mathrm{NH}_{4} \mathrm{OH}-\mathrm{GO}$ and $\mathrm{NH}_{4} \mathrm{Cl}-\mathrm{GO}$ films may experience similar interactions with the $\mathrm{CO}_{2}$ gas produced during thermal treatment, leading to these membranes retaining more intercalated $\mathrm{CO}_{2}$. 
Section 8: Probe Molecule Deliveries to GO and Ion Modified GO Membranes
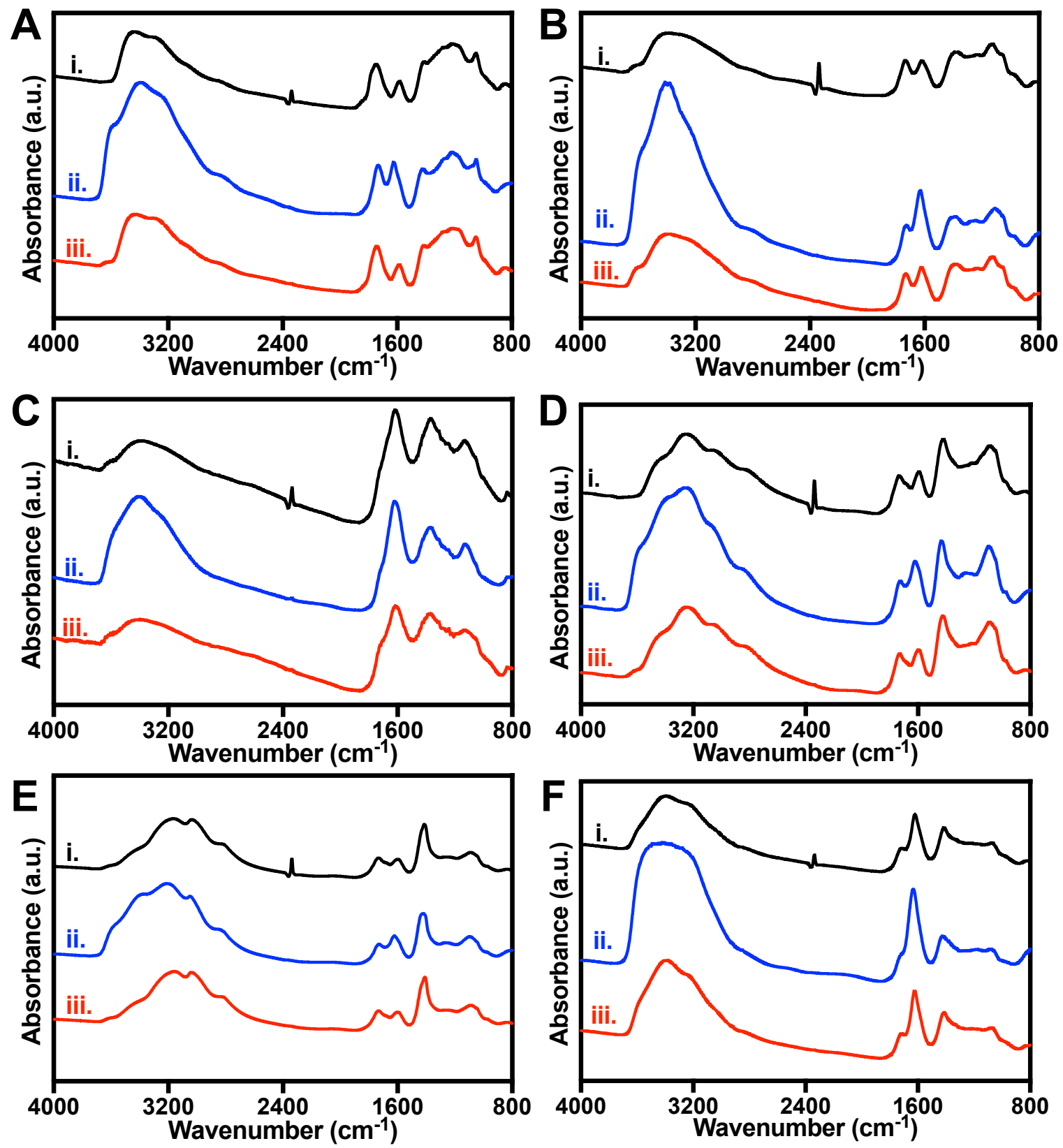

Figure S19: IR spectra for water deliveries to GO membranes following thermal treatment at 125 ${ }^{\circ} \mathrm{C}$ for 10 min. (A) GO, (B) NaCl-GO, (C) NaOH-GO, (D) $\mathrm{NH}_{4} \mathrm{OH}-\mathrm{GO}$, (E) $\mathrm{NH}_{4} \mathrm{Cl}-\mathrm{GO}$ and (F) $\mathrm{CaCl}_{2}$-GO. (i) vacuum $\left(10^{-4} \mathrm{mbar}\right)$, (ii) water contact (5 min), (iii) outgas $\left(10^{-4} \mathrm{mbar}\right)$. 

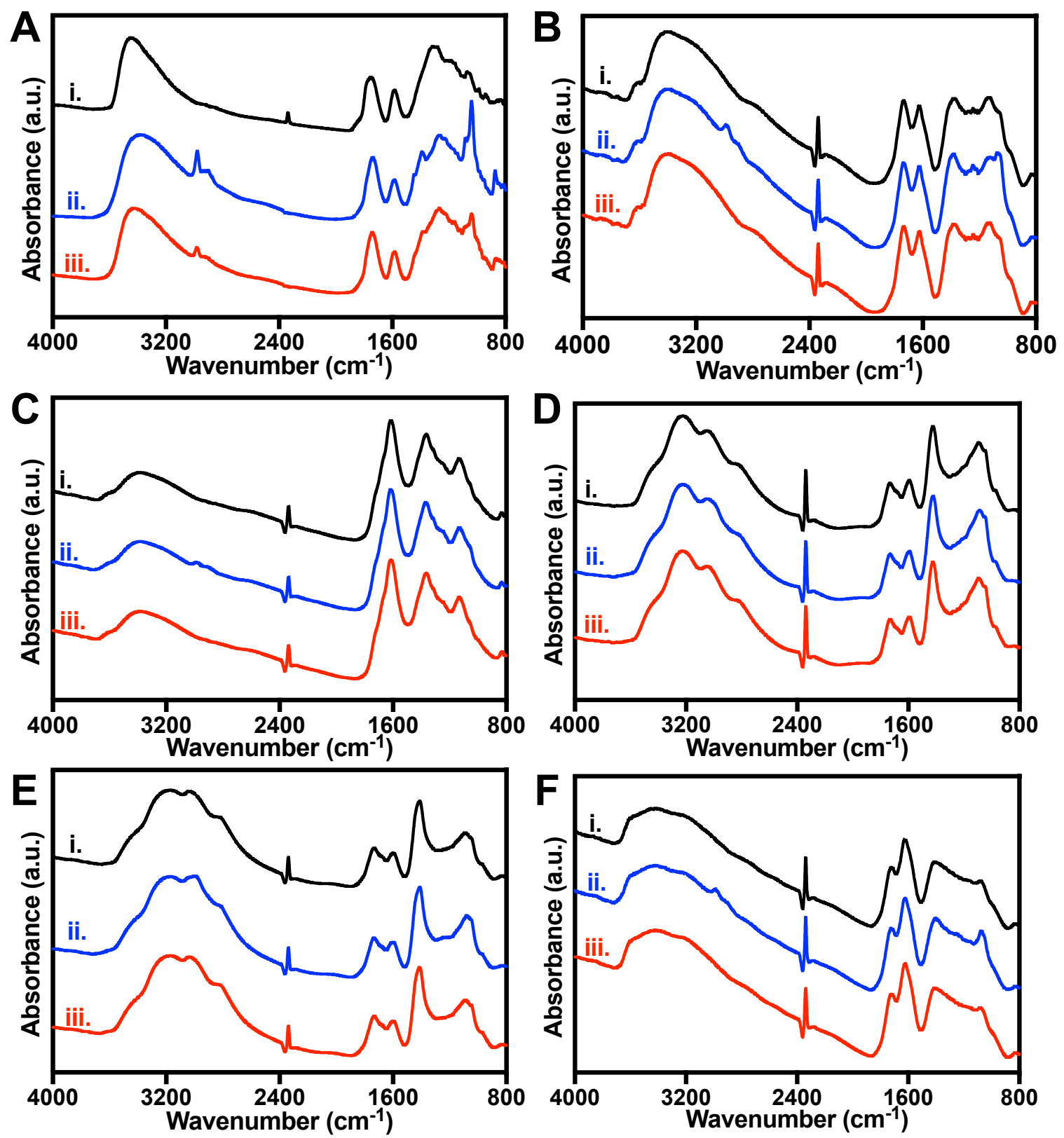

Figure S20: IR spectra for $\mathrm{EtOH}$ deliveries to $\mathrm{GO}$ membranes following thermal treatment at 125 ${ }^{\circ} \mathrm{C}$ for 10 min. (A) GO, (B) NaCl-GO, (C) NaOH-GO, (D) NH $4 \mathrm{NH}_{4} \mathrm{OHO}$, (E) $\mathrm{NH}_{4} \mathrm{Cl}-\mathrm{GO}$ and (F) $\mathrm{CaCl}_{2}$-GO. (i) vacuum (10-4 mbar), (ii) $\mathrm{EtOH}$ contact (30 min in (A), $180 \mathrm{~min}$ in all others), (iii) outgas $\left(10^{-4} \mathrm{mbar}\right)$. 
For GO and all ion modified GO membranes the intercalated $\mathrm{CO}_{2}$ signal (Figure S19-i) disappears within 5 min of water vapor contact (Figure $\mathrm{S} 19$-ii) and all $\mathrm{CO}_{2}$ is removed from the cell upon outgassing (Figure S19-iii). ${ }^{15}, 17$ While EtOH displaces the intercalated $\mathrm{CO}_{2}$ in GO (Figure S20A), it is incapable of doing so in the ion modified GO, as the intercalated $\mathrm{CO}_{2}$ signal (Figure S20B through F-i) remains unchanged during EtOH admission (Figure S20B through Fii) and all EtOH is removed upon outgassing (Figure S20B through F-iii). ${ }^{17,} 19$ The intercalation behavior for water and $\mathrm{EtOH}$ into $\mathrm{GO}$ and ion modified $\mathrm{GO}$ agrees with the permeation behavior (Figure 2C and D). 

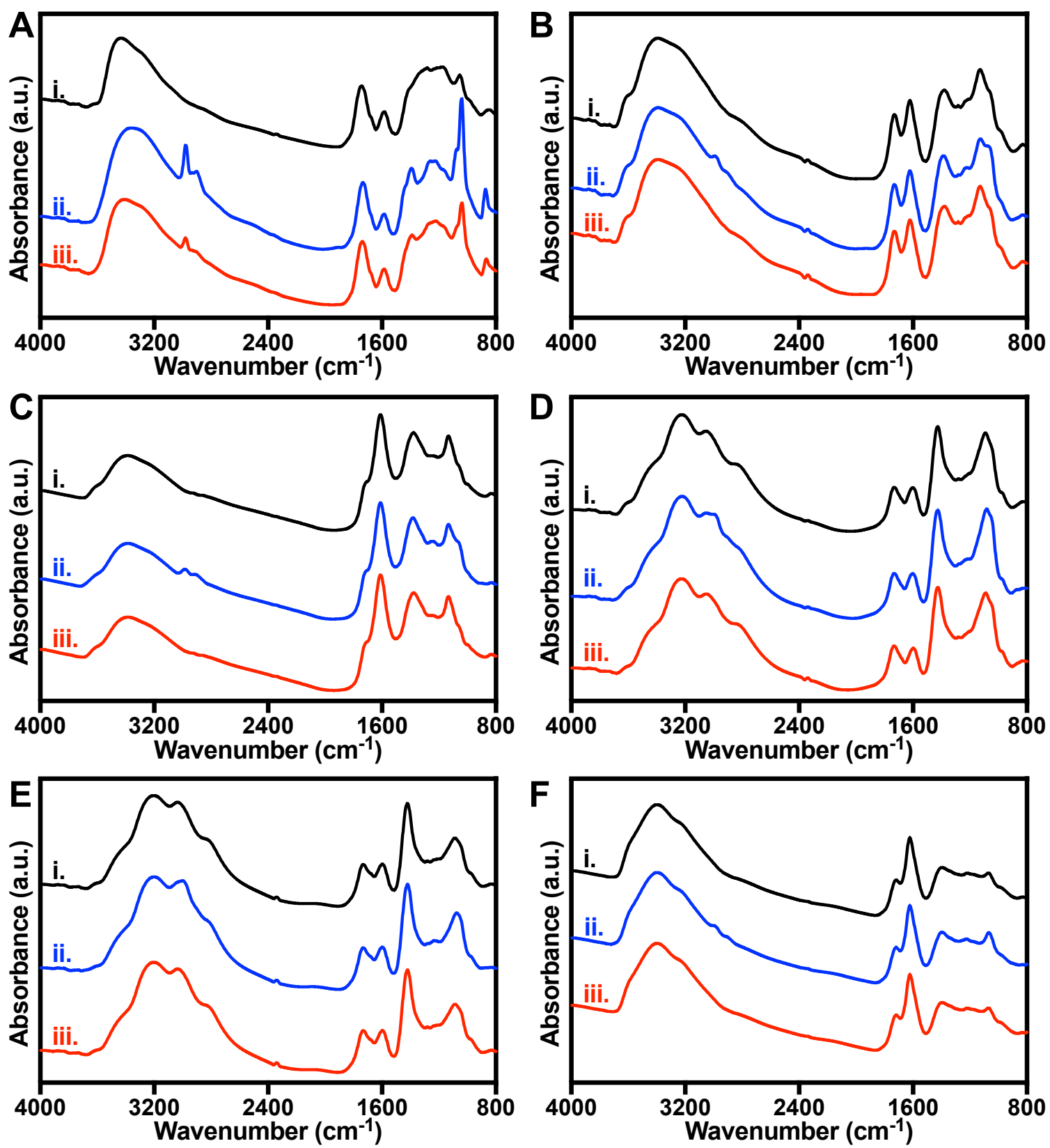

Figure S21: IR spectra for EtOH deliveries to unmodified and ion modified $\mathrm{GO}$ at room temperature. (A) GO, (B) NaCl-GO, (C) NaOH-GO, (D) $\mathrm{NH}_{4} \mathrm{OH}-\mathrm{GO}$, (E) $\mathrm{NH}_{4} \mathrm{Cl}-\mathrm{GO}$ and (F) $\mathrm{CaCl}_{2}$-GO. (i) vacuum (10-4 $\left.\mathrm{mbar}\right)$, (ii) $\mathrm{EtOH}$ contact $(30 \mathrm{~min})$ and (iii) outgas $\left(10^{-4} \mathrm{mbar}\right)$. 
In $\mathrm{GO}$ the strong EtOH peaks (Figure S21A-ii) remain present under vacuum (Figure S21A-iii). ${ }^{19}$ In ion modified GO the EtOH peaks are weaker (Figure S21B through F-ii) and disappear after outgassing (Figure S21B through F-iii). This shows that EtOH will readily intercalate into $\mathrm{GO}$ at room temperature but is incapable of intercalating into ion modified GO, in agreement with the behavior observed for $\mathrm{GO}$ treated at $125^{\circ} \mathrm{C}$ for $10 \mathrm{~min}$ (Figure S20). 

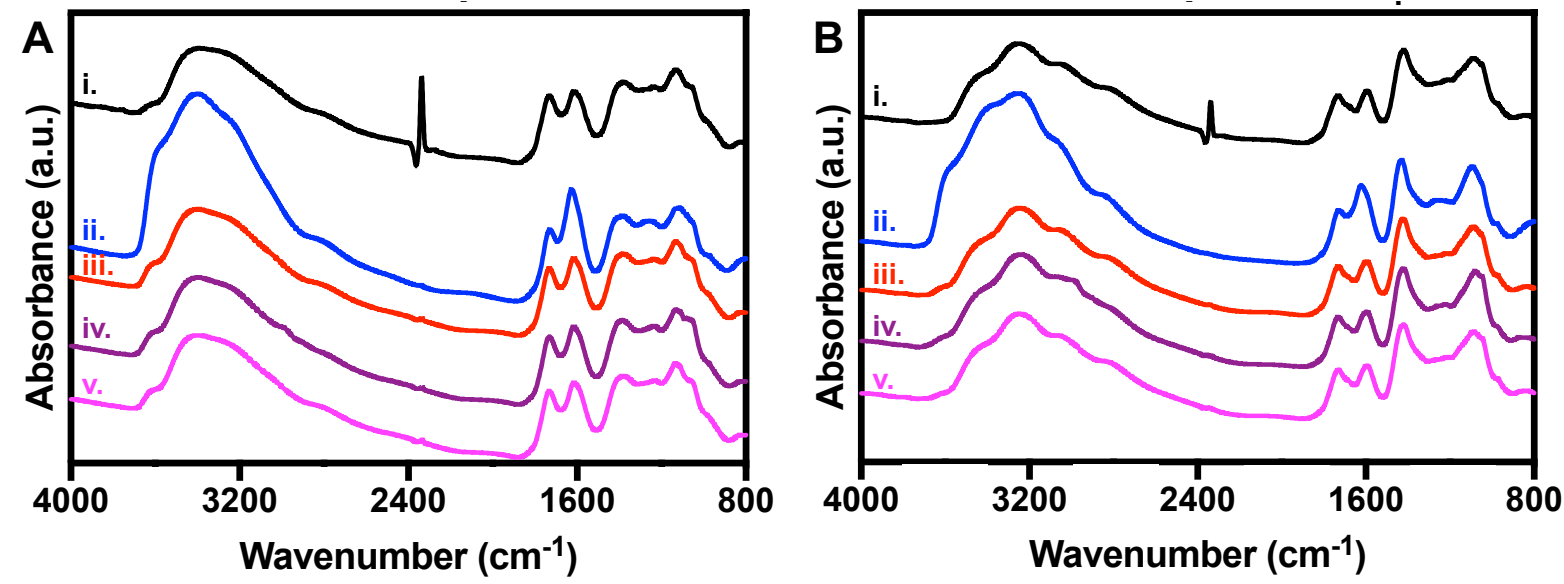

Figure S22: IR spectra for sequential water and EtOH deliveries to (A) NaCl-GO and (B) $\mathrm{NH}_{4} \mathrm{OH}-\mathrm{GO}$ samples following thermal treatment at $125^{\circ} \mathrm{C}$ for $10 \mathrm{~min}$. (i) vacuum $\left(10^{-4} \mathrm{mbar}\right)$, (ii) water contact (15 min), (iii) first outgas $\left(10^{-4} \mathrm{mbar}\right)$, (iv) EtOH contact (30 min) and (v) second outgas $\left(10^{-4} \mathrm{mbar}\right)$.

As before for $\mathrm{NaCl}-\mathrm{GO}$ and $\mathrm{NH}_{4} \mathrm{OH}-\mathrm{GO}$ the intercalated $\mathrm{CO}_{2}$ signal (Figure $\mathrm{S} 22 \mathrm{~A}$ and $\mathrm{B}$ i) disappears quickly with water vapor contact (Figure $\mathrm{S} 22 \mathrm{~A}$ and $\mathrm{B}-\mathrm{ii}$ ) and all $\mathrm{CO}_{2}$ is removed from the cell upon outgassing (Figure S22A and B-iii). ${ }^{15,17}$ When EtOH is delivered to the same sample the strong EtOH peaks (Figure S22A and B-iv) vanish following a second outgas (Figure S22A and B-v), indicating that the ions still successfully prevent EtOH intercalation after additional water saturation. ${ }^{19}$ 


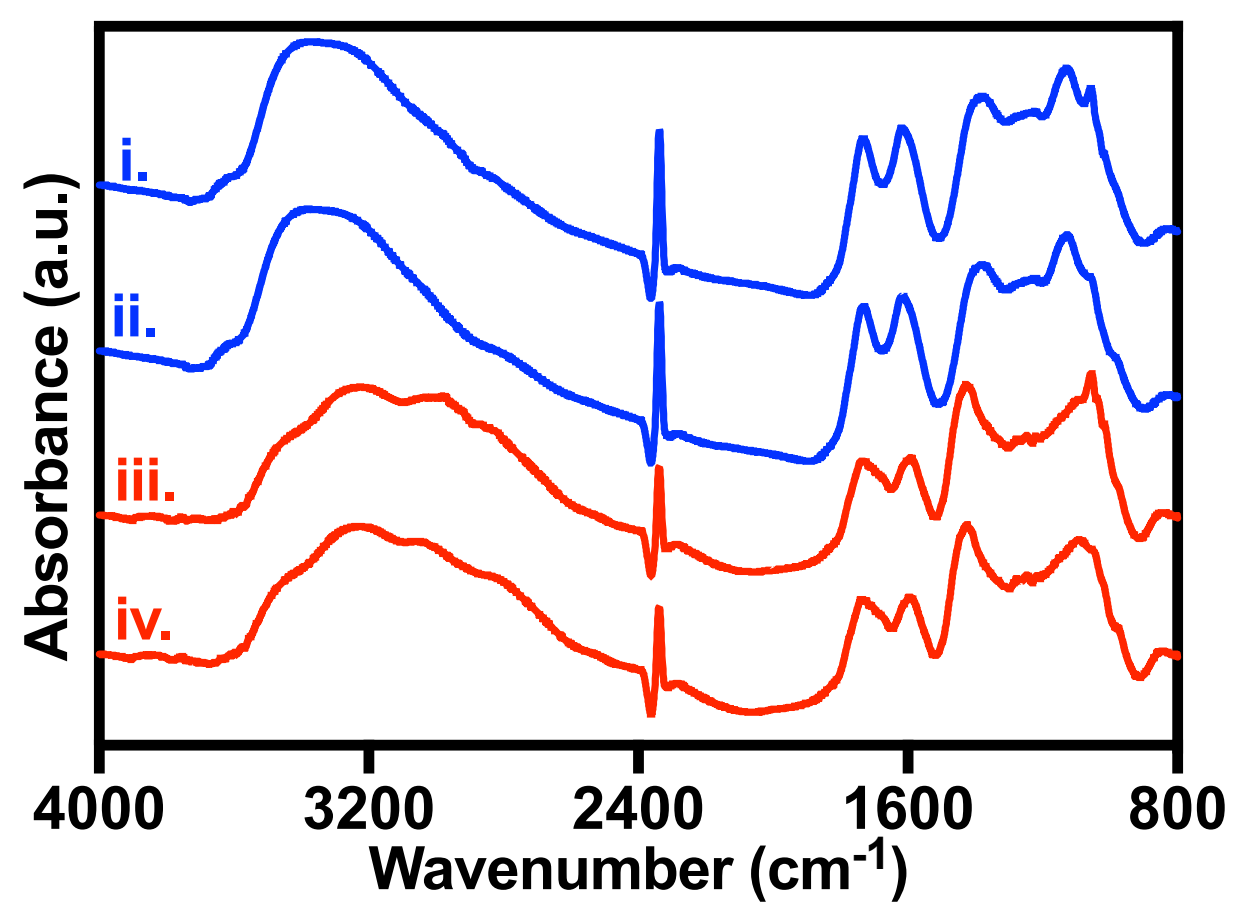

Figure S23: IR spectra for $\mathrm{MeOH}$ deliveries to ion modified GO membranes following thermal treatment at $125^{\circ} \mathrm{C}$ for $10 \mathrm{~min}$. NaCl-GO (i) $\mathrm{MeOH}$ contact (30 min) and (ii) outgas $\left(10^{-4} \mathrm{mbar}\right.$ ) and $\mathrm{NH}_{4} \mathrm{OH}-\mathrm{GO}$ (iii) $\mathrm{MeOH}$ contact (30 min) and (iv) outgas ( $\left.10^{-4} \mathrm{mbar}\right)$.

We previously showed $\mathrm{MeOH}$ will readily intercalate into $\mathrm{GO}$ membranes following short thermal treatment. ${ }^{14} \mathrm{MeOH}$ cannot intercalate in NaCl-GO or $\mathrm{NH}_{4} \mathrm{OH}-\mathrm{GO}$ membranes, despite the $\mathrm{MeOH}$ molecule having a smaller size and a higher polarity than $\mathrm{EtOH},{ }^{20}$ as shown by the intercalated $\mathrm{CO}_{2}$ signals continued presence (Figure $\mathrm{S} 23-\mathrm{i}$ and iii) under $\mathrm{MeOH}$ and the complete removal of MeOH signals upon outgassing (Figure S23-ii and iv). ${ }^{19}$ 

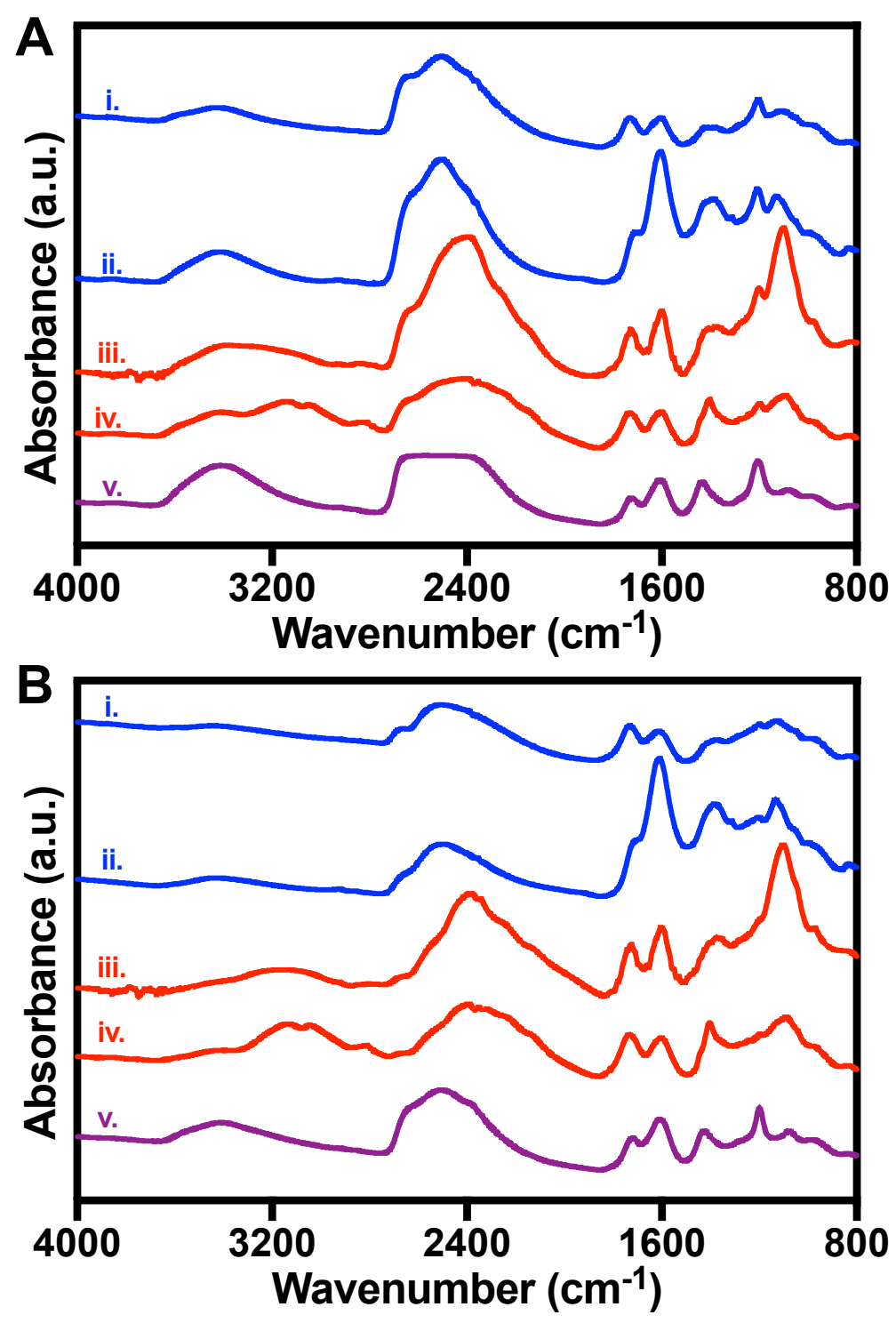

Figure S24: IR spectra for heavy water deliveries to ion modified GO membranes at room temperature. (A) Heavy water contact (5 min) and (B) outgas ( $10^{-4} \mathrm{mbar}$ ). (i) $\mathrm{NaCl}-\mathrm{GO}$, (ii) $\mathrm{NaOH}-\mathrm{GO}$, (iii) $\mathrm{NH}_{4} \mathrm{OH}-\mathrm{GO}$, (iv) $\mathrm{NH}_{4} \mathrm{Cl}-\mathrm{GO}$ and (v) $\mathrm{CaCl}_{2}-\mathrm{GO}$.

Upon heavy water admission, the $v_{\mathrm{O}-\mathrm{H}}$ signal decreases and a band corresponding to the $v_{O}-D$ signal of heavy water probe molecules appears between $\sim 2000-2700 \mathrm{~cm}^{-1}$ (Figure S24A). ${ }^{15}$ Following outgassing (Figure S24B) the $v_{\mathrm{O}-\mathrm{H}}$ signal decreases further and the $v_{\mathrm{O}-\mathrm{D}}$ signal persists. These results indicate that ion modified GO membranes contain a significant amount of water under ambient conditions and that some of this water is retained under vacuum. Following 
outgassing, the $\mathrm{NaCl}-\mathrm{GO}, \mathrm{NaOH}-\mathrm{GO}$ and $\mathrm{CaCl}_{2}-\mathrm{GO}$ exhibit a stronger $v_{\mathrm{O}-\mathrm{D}}$ at $\sim 2600 \mathrm{~cm}^{-1}$ than the other membranes. Similar to the removal of physisorbed water (Figure S17B), this indicates the sodium or calcium modified membranes hold more intercalated heavy water under vacuum due to strong coordination between the $\mathrm{Na}^{+}$or $\mathrm{Ca}^{2+}$ ions and the heavy water molecules in the GO. ${ }^{16}$ 
Section 9: Characterization for NaCl-GO Membranes with Varying Ion Concentrations

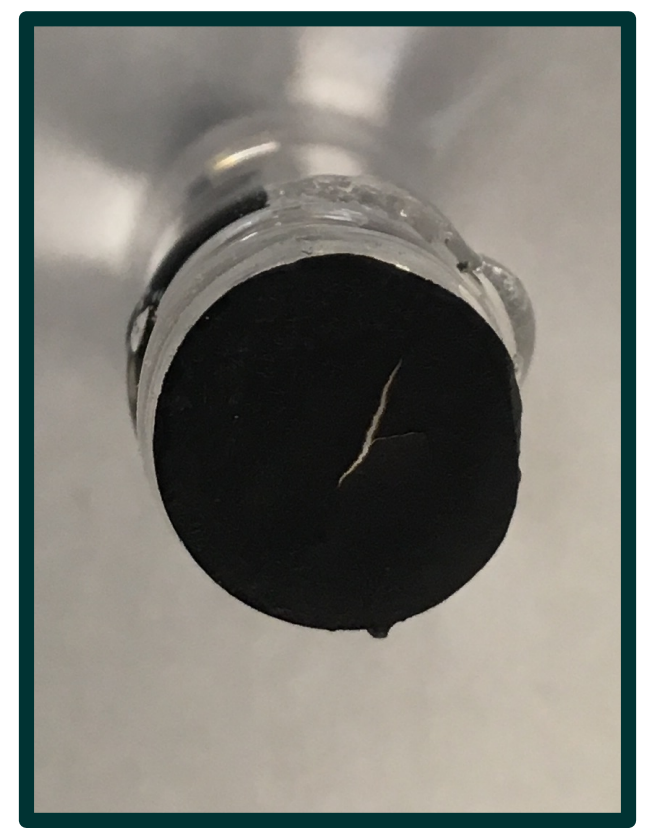

Figure S25: Macroscopic defects in $0.1 \mathrm{M} \mathrm{NaCl-GO}$ membrane

A

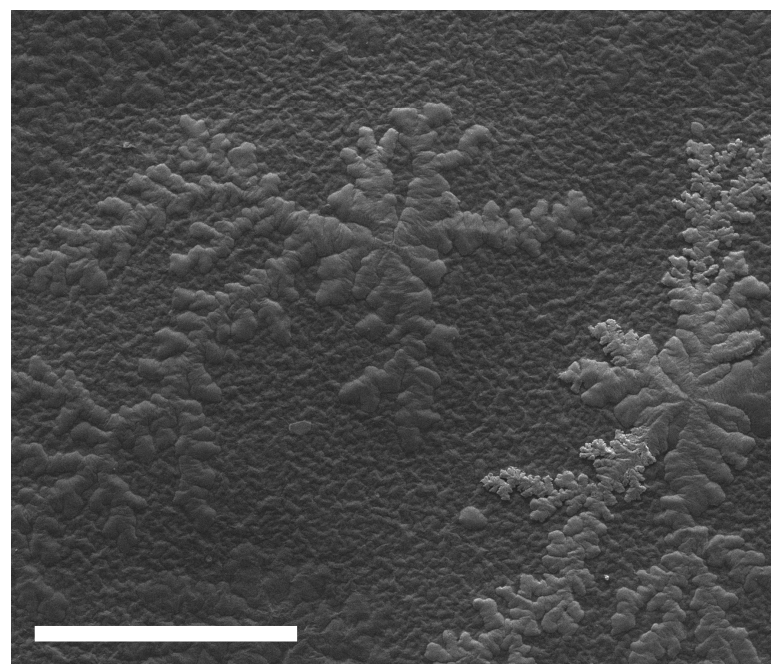

B

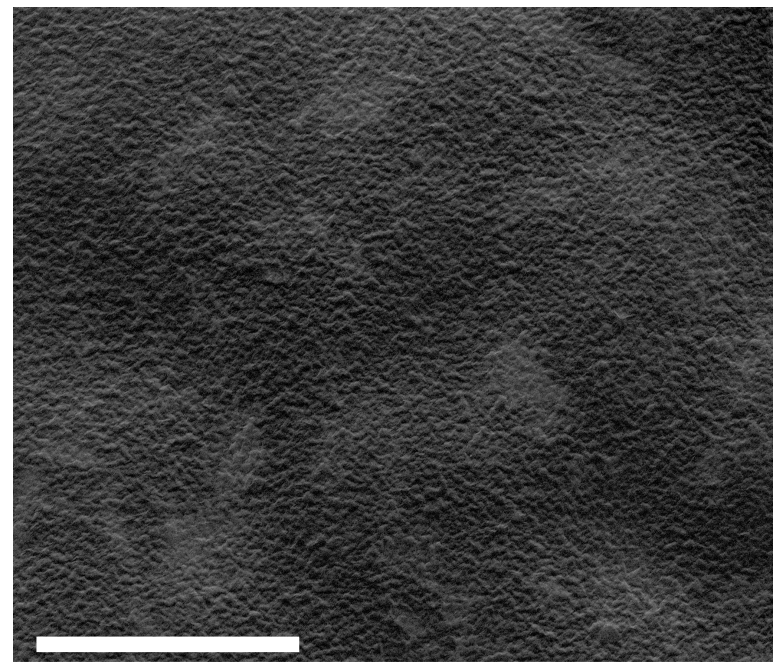

Figure S26: SEM images for $\mathrm{NaCl}-\mathrm{GO}$ membranes with varying $\mathrm{NaCl}$ concentrations. (A) 0.1 $\mathrm{M}$ and (B) $0.001 \mathrm{M} \mathrm{NaCl-GO}$. All scale bars are set at $500 \mu \mathrm{m}$. 


\section{Section 10: Acid-Base Titrations}

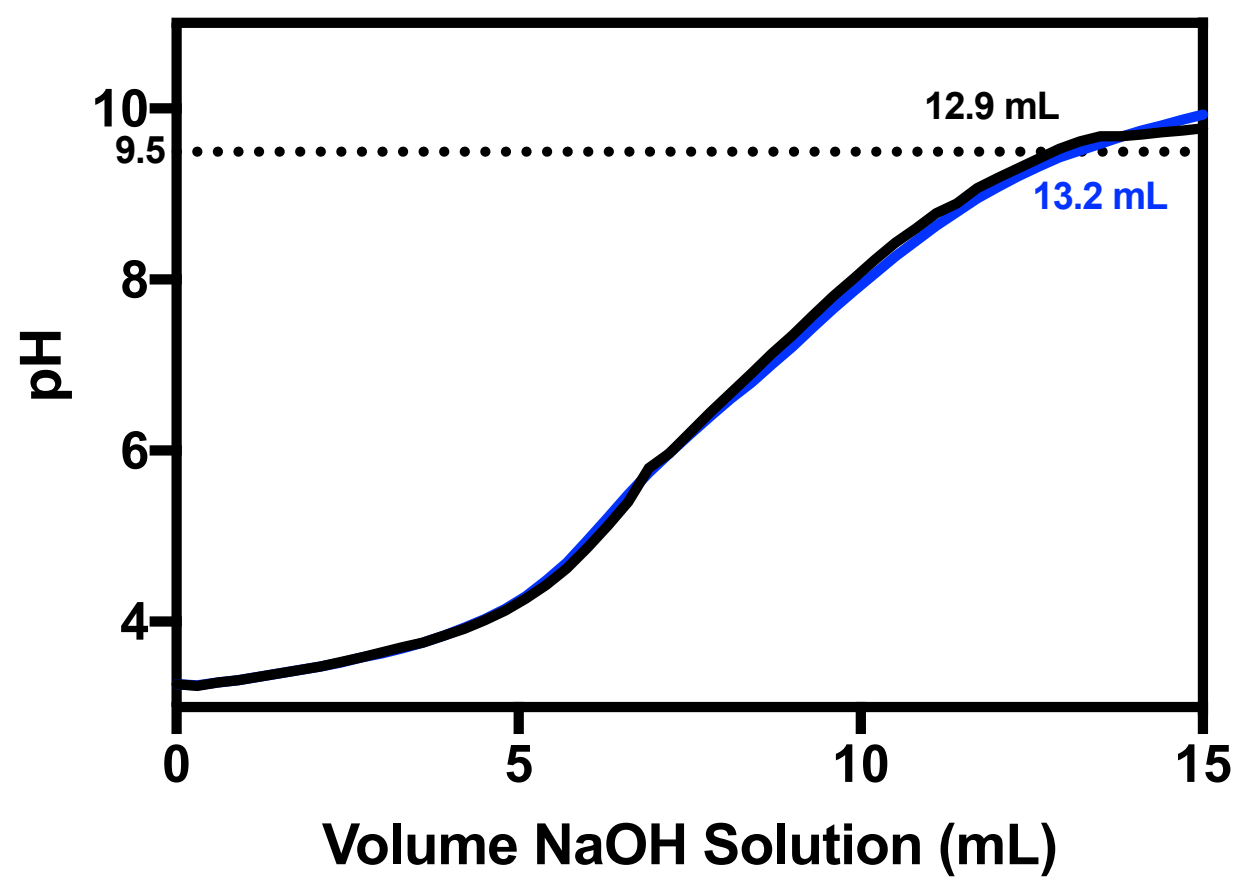

Figure S27: Results of $\mathrm{NaOH}$ titration for $0.5 \mathrm{mg} \mathrm{mL}^{-1} \mathrm{GO}$ suspension.

The bend in the titration curve ( $\mathrm{pH} \sim 9.5$ in Figure $\mathrm{S} 27$ ) is taken to be the point where $\sim 90 \%$ of acidic groups have been neutralized. ${ }^{12}$ The two experimental runs required $\mathrm{NaOH}$ volumes of $12.9 \mathrm{~mL}$ and $13.2 \mathrm{~mL}$ to reach this point. The calculations below show that our GO contains $\sim 360$ mMol of acidic sites per $100 \mathrm{~g}$ of sample.

Experimental Run 1:

$$
\begin{gathered}
0.0129 \mathrm{~L} \cdot 0.0025 \frac{\mathrm{mol}}{\mathrm{L}}=3.225 \cdot 10^{-5} \mathrm{~mol} \mathrm{NaOH} \\
\frac{3.225 \cdot 10^{-5} \mathrm{~mol} \mathrm{NaOH}}{0.9 \frac{\mathrm{mol} \mathrm{NaOH}}{\mathrm{mol} \mathrm{acidic} \mathrm{group}}}=3.583 \cdot 10^{-5} \frac{\mathrm{mol} \text { acidic group }}{10 \mathrm{mg} \mathrm{GO}}=0.03583 \frac{\mathrm{mmol} \text { acidic group }}{10 \mathrm{mg} \mathrm{GO}} \\
0.03583 \frac{\mathrm{mmol} \mathrm{acidic} \mathrm{group}}{10 \mathrm{mg} \mathrm{GO}}=358.3 \frac{\mathrm{mmol} \text { acidic group }}{100 \mathrm{~g} \mathrm{GO}}
\end{gathered}
$$


Experimental Run 2:

$$
\begin{gathered}
0.0132 \mathrm{~L} \cdot 0.0025 \frac{\mathrm{mol}}{\mathrm{L}}=3.3 \cdot 10^{-5} \mathrm{~mol} \mathrm{NaOH} \\
\frac{3.3 \cdot 10^{-5} \mathrm{~mol} \mathrm{NaOH}}{0.9 \frac{\mathrm{mol} \mathrm{NaOH}}{\mathrm{mol} \mathrm{acidic} \mathrm{group}}}=3.67 \cdot 10^{-5} \frac{\mathrm{mol} \mathrm{acidic} \mathrm{group}}{10 \mathrm{mg} \mathrm{GO}}=0.0367 \frac{\mathrm{mmol} \text { acidic group }}{10 \mathrm{mg} \mathrm{GO}} \\
0.0367 \frac{\mathrm{mmol} \mathrm{acidic} \mathrm{group}}{10 \mathrm{mg} \mathrm{GO}}=367 \frac{\mathrm{mmol} \mathrm{acidic} \mathrm{group}}{100 \mathrm{~g} \mathrm{GO}}
\end{gathered}
$$

Table S3: Maximum Percentage of Occupied Acidic Sites as Determined by Acid-Base Titration. Assuming $10 \mathrm{~mL}$ of suspension and $\sim 360 \mathrm{mmol}$ of Acidic Sites per $100 \mathrm{~g}$ of GO.

\begin{tabular}{|c|c|c|c|c|c|}
\hline $\begin{array}{c}\text { NaCl Concentration } \\
\text { (M) }\end{array}$ & $\begin{array}{c}\mathbf{N a}^{+} \text {lons } \\
\text { (mmol) }\end{array}$ & $\begin{array}{c}\text { GO Concentration } \\
\left(\mathbf{m g ~ m L}^{-1}\right)\end{array}$ & $\begin{array}{c}\text { Mass GO } \\
(\mathbf{m g})\end{array}$ & $\begin{array}{c}\text { Number of Acidic Sites } \\
\text { (mmol) }\end{array}$ & $\begin{array}{c}\text { Maximum Occupied Acidic Sites } \\
\text { (\%) }\end{array}$ \\
\hline $\mathbf{0 . 0 2}$ & 0.2 & 5 & 50 & 0.18 & 111 \\
\hline $\mathbf{0 . 1}$ & 1 & 4 & 40 & 0.144 & 694 \\
\hline $\mathbf{0 . 0 5}$ & 0.5 & 4 & 40 & 0.144 & 347 \\
\hline $\mathbf{0 . 0 1}$ & 0.1 & 4 & 40 & 0.144 & 69 \\
\hline $\mathbf{0 . 0 0 7 5}$ & 0.075 & 4 & 40 & 0.144 & 52 \\
\hline $\mathbf{0 . 0 0 5}$ & 0.05 & 4 & 40 & 0.144 & 35 \\
\hline $\mathbf{0 . 0 0 1}$ & 0.01 & 4 & 40 & 0.144 & 7 \\
\hline
\end{tabular}

Example Calculation:

$$
\begin{gathered}
0.01 \mathrm{~L} \cdot 0.02 \mathrm{M}=2 \cdot 10^{-4} \mathrm{~mol} \mathrm{Na}=0.2 \mathrm{mmol} \mathrm{Na}^{+} \\
50 \mathrm{mg} \mathrm{GO} \cdot 0.0036 \frac{\mathrm{mmol} \text { acidic sites }}{1 \mathrm{mg} \mathrm{GO}}=0.18 \mathrm{mmol} \text { acidic sites } \\
\frac{0.2 \mathrm{mmol} \mathrm{Na}}{0.18 \mathrm{mmol} \text { acidic sites }} \cdot 100 \%=111.11 \%=\sim 111 \%
\end{gathered}
$$




\section{Corresponding Author}

*Marta Cerruti

Email: marta.cerruti@mcgill.ca

Tel: 1 (514) 398-5498

\section{Supplemental References:}

(1) Wang, M.; Niu, Y.; Zhou, J.; Wen, H.; Zhang, Z.; Luo, D.; Gao, D.; Yang, J.; Liang, D.; Li, Y. The dispersion and aggregation of graphene oxide in aqueous media. Nanoscale 2016, 8 (30), 14587-14592.

(2) Park, S.; Lee, K.-S.; Bozoklu, G.; Cai, W.; Nguyen, S. T.; Ruoff, R. S. Graphene Oxide Papers Modified by Divalent Ions-Enhancing Mechanical Properties via Chemical Cross-Linking. ACS Nano 2008, 2 (3), 572-578.

(3) Silverberg, G. J.; Vecitis, C. D. Wrinkling and Periodic Folding of Graphene Oxide Monolayers by Langmuir-Blodgett Compression. Langmuir 2017, 33 (38), 9880-9888.

(4) Yao, B.; Chen, J.; Huang, L.; Zhou, Q.; Shi, G. Base-Induced Liquid Crystals of Graphene Oxide for Preparing Elastic Graphene Foams with Long-Range Ordered Microstructures. Advanced Materials 2016, 28 (8), 1623-1629.

(5) Shih, C.-J.; Lin, S.; Sharma, R.; Strano, M. S.; Blankschtein, D. Understanding the pHDependent Behavior of Graphene Oxide Aqueous Solutions: A Comparative Experimental and Molecular Dynamics Simulation Study. Langmuir 2012, 28 (1), 235-241.

(6) Long, Y.; Wang, K.; Xiang, G.; Song, K.; Zhou, G.; Wang, X. Molecule Channels Directed by Cation-Decorated Graphene Oxide Nanosheets and Their Application as Membrane Reactors. Advanced Materials 2017, 29 (16).

(7) Viinikanoja, A.; Wang, Z.; Kauppila, J.; Kvarnstrom, C. Electrochemical reduction of graphene oxide and its in situ spectroelectrochemical characterization. Physical Chemistry Chemical Physics 2012, 14 (40), 14003-14009.

(8) Lin, X.; Shen, X.; Sun, X.; Liu, X.; Wu, Y.; Wang, Z.; Kim, J.-K. Graphene Oxide Papers Simultaneously Doped with $\mathrm{Mg} 2+$ and $\mathrm{Cl}-$ for Exceptional Mechanical, Electrical, and Dielectric Properties. ACS Applied Materials \& Interfaces 2016, 8 (3), 2360-2371.

(9) Tan, P.; Sun, J.; Hu, Y.; Fang, Z.; Bi, Q.; Chen, Y.; Cheng, J. Adsorption of Cu2+, Cd2+ and $\mathrm{Ni} 2+$ from aqueous single metal solutions on graphene oxide membranes. Journal of Hazardous Materials 2015, 297, 251-260.

(10) Acik, M.; Mattevi, C.; Gong, C.; Lee, G.; Cho, K.; Chhowalla, M.; Chabal, Y. J. The Role of Intercalated Water in Multilayered Graphene Oxide. ACS Nano 2010, 4 (10), 5861-5868.

(11) Acik, M.; Lee, G.; Mattevi, C.; Pirkle, A.; Wallace, R. M.; Chhowalla, M.; Cho, K.; Chabal, Y. The Role of Oxygen during Thermal Reduction of Graphene Oxide Studied by Infrared Absorption Spectroscopy. Journal of Physical Chemistry C 2011, 115 (40), 19761-19781.

(12) Dimiev, A. M.; Alemany, L. B.; Tour, J. M. Graphene Oxide. Origin of Acidity, Its Instability in Water, and a New Dynamic Structural Model. ACS Nano 2013, 7 (1), 576-588. 
(13) Max, J.-J.; Chapados, C. Aqueous ammonia and ammonium chloride hydrates: Principal infrared spectra. Journal of Molecular Structure 2013, 1046, 124-135.

(14) Church, R. B.; Hu, K.; Magnacca, G.; Cerruti, M. Intercalated Species in Multilayer Graphene Oxide: Insights Gained from In Situ FTIR Spectroscopy with Probe Molecule Delivery. The Journal of Physical Chemistry C 2016, 120 (40), 23207-23211.

(15) Bonner, O. D.; Curry, J. D. Infrared spectra of liquid H2O and D2O. Infrared Physics 1970, $10(2), 91-94$.

(16) Cerruti, M.; Bianchi, C. L.; Bonino, F.; Damin, A.; Perardi, A.; Morterra, C. Surface modifications of bioglass immersed in TRIS-buffered solution. A multitechnical spectroscopic study. The Journal of Physical Chemistry B 2005, 109 (30), 14496-14505.

(17) Eigler, S.; Dotzer, C.; Hirsch, A.; Enzelberger, M.; Müller, P. Formation and Decomposition of CO2 Intercalated Graphene Oxide. Chemistry of Materials 2012, 24 (7), 1276-1282.

(18) Yeh, J. T.; Resnik, K. P.; Rygle, K.; Pennline, H. W. Semi-batch absorption and regeneration studies for $\mathrm{CO} 2$ capture by aqueous ammonia. Fuel Processing Technology 2005, 86 (14), 1533 1546.

(19) Plyler, E. K. Infrared Spectra of Methanol, Ethanol and n-Propanol. Journal of Research of the National Bureau of Standards 1952, 48 (4), 281-286.

(20) Liu, R.; Arabale, G.; Kim, J.; Sun, K.; Lee, Y.; Ryu, C.; Lee, C. Graphene oxide membrane for liquid phase organic molecular separation. Carbon 2014, 77, 933-938. 